\title{
A Urbanização da Amazónia e do Mato Grosso no século XVIII Povoações civis, decorosas e úteis para o bem comum da coroa e dos povos
}

\section{Renata Malcher de Araujo ${ }^{1}$}

RESUMO: Neste texto faz-se uma leitura sintética do processo de urbanização da região amazônica e do Mato Grosso, na segunda metade do século XVIII. Consideram-se, sobretudo, as relações implícitas com a conjuntura da demarcação de limites; a projeção ideológica do urbano no discurso político das Luzes, que se reflete na legislação adotada, e as implicações do processo de urbanização na leitura do território.

PalAVRAS-CHAVE: Urbanização. Amazónia. Mato Grosso. Grão-Pará. Fronteiras. Legislação indigenista. Território.

ABSTRACT: In this paper we make a concise reading of the urbanization of the Amazon and Mato Grosso in the second half of the eighteenth century. We consider, above all, the implicit relations with the conjuncture of the demarcation of boundaries; the ideological projection of the urban in the political discourse of the Enlightenment, that is reflected in the legislation adopted and the implications of the urbanization process in the reading of the territory.

KEYWORDS: Urbanization. Amazon. Mato Grosso. Grão-Pará. Borders. Indianist legislation. Territory.

Introdução

A organizadora deste dossiê pediu-me para redigir uma síntese sobre a urbanização da Amazónia e do Mato Grosso, tendo em conta que ambas as regiões foram, respectivamente, os objetos de trabalho das minhas dissertações de mestrado (1992) e doutorado (2001)². Peço que me permitam começar este

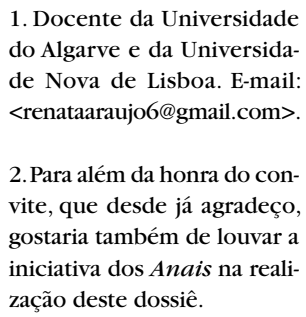

zação deste dossiê. 
3. CONSUlTA do Conselho sobre os novos governos em Goiás e Mato Grosso. "O Governo de São Paulo não se erigiu porque se reputasse necessário para aquelas duas comarcas, senão porque sendo então por São Paulo o caminho, e comunicação das Minas Gerais pareceu preciso criar naquela parte Governador".AHU Mato Grosso caixa 4 doc 2 - 29 de Janeiro de 1748 .

4. Ibidem. texto contado um breve episódio, um tanto anedótico, que se passou comigo precisamente quando eu estava fazendo o doutoramento. Uma colega perguntoume sobre o que era o meu trabalho. Eu disse-the o título: A Urbanização do Mato Grosso no século XVIII: Discurso e Método. Ela ouviu. Imediatamente depois, quando outra pessoa the perguntou sobre o que era 0 trabalho, ela resolveu resumir e disse: "é sobre umas cidades que cresceram no mato". Fiquei mais divertida que aborrecida com a simplificação (até podia adotar a frase como explicação sintética das duas teses, pois, em qualquer dos casos, fizeram-se várias cidades no mato). Mas o que me pareceu mais interessante é que a frase denunciava uma espécie de paradoxo implícito no tema. Um paradoxo que opõe duas palavras naturalmente lidas como opostos uma da outra, urbanização e mato. Tão forte é o sentido de oposição entre estas palavras, que soa estranho pensar em cidades no mato. Mas foi de certo modo a força deste contraste que esteve na base do próprio processo de urbanização da Amazónia e do Mato Grosso. Porque ali, mais do que em qualquer outra região do Brasil, as cidades representavam elementos discursivos enfáticos da relação de domínio sobre o território que se pretendia estabelecer ou, antes, reivindicar. E a decisão de as fazer, várias, e no mato, implicou uma importante e significativa mudança na leitura do próprio território.

O marco fundamental a ter em conta aqui é, naturalmente, a assinatura do Tratado de Madrid, em 1750. Com efeito, a cronologia da urbanização da Amazónia e do Mato Grosso decorre sobretudo na segunda metade do século XVIII e parte fundamental do seu enquadramento é a conjuntura das demarcações de limites entre as coroas de Portugal e Espanha.

antemural do Brasil

Em especial para o caso do Mato Grosso, importa ver os antecedentes da discussão do tratado para enquadrar corretamente a decisão de criar governos autónomos nas capitanias de Goiás e Mato Grosso, desmembrando-as da capitania de São Paulo. O Conselho Ultramarino justificava a decisão afirmando que o governo em São Paulo tinha sido criado, não por ser necessário, mas porque era $\circ$ "caminho"3 para as minas e que, dadas as novas circunstâncias, era necessário que as próprias minas tivessem governo autónomo. Especificamente sobre a capitania do Mato Grosso, esperava-se que "por meio do estabelecimento do Governo, como por todos os outros que ocorrerem se procure fazer a Colonia do Mato Grosso tão poderoza, que contenha os vizinhos em respeito, e sirva de antemural a todo o interior do Brazil"4.

As instruções que foram passadas ao governador da nova capitania eram claras quanto às prioridades a seguir. Os sete primeiros itens diziam respeito à fundação de uma nova vila, já antes prevista, que seria a cabeça do governo da capitania e onde deveria residir o governador. Para tal, recomendava-se que 
esta se situasse no distrito do Mato Grosso, ainda que o de Cuiabá fosse mais populoso, e que se fizesse "em lugar defensável e quanto for possível vizinho ao rio Guaporé". Para incentivar a vinda de povoadores, a Coroa concedia isenções e privilégios aos habitantes da nova vila, na qual o governador deveria ter o "cuidado de mandar traçar as ruas direitas e largas, o mais que vos parecer conveniente, para que a mesma vila desde o principio se estabeleça com boa direcção". Havia que mandar fazer casa para morada dos governadores "com aquella decencia e comodidade que vos parecer necessaria e bastante", assim como quartéis para acomodar a guarda de dragões ${ }^{5}$.

As questões relativas aos cuidados a tomar com os vizinhos castelhanos, especialmente na área de Moxos, ocupavam dez itens das instruções. Os índios ocupavam outros oito pontos do rol das recomendações, alertando-se o governador quanto às precauções que deveria ter com as nações hostis, que continuavam a atacar as monções, assim como quanto às providências que deveria tomar para aldear os índios "mansos". Apenas os dois últimos itens das instruções de governo, diziam respeito às minas. Recomendava-se a execução de uma conduta de água para garantir a mineração de uma área recentemente descoberta e voltava-se a proibir, por todos os meios, a extração de diamantes. Para os outros problemas que pudessem ocorrer, confiava-se na prudência e no zelo do governador nomeado, D. António Rolim de Moura.

Do conjunto de indicações recomendadas a Rolim de Moura, sobressaem-se as questões de ordem territorial. A fronteira perpassa praticamente todos os itens das instruções. $\bigcirc$ documento evidencia que a presença do governador deveria funcionar como o garante da defesa militar do território, o que era reforçado pela criação de um corpo de dragões sob o seu comando. Mas, a despeito das precauções de ordem militar, a abordagem feita ao território parte, sobretudo, de uma visão jurídica.

A primeira providência política no sentido de incorporar aquele território ao controle fiscal e administrativo da Coroa tinha sido a criação da vila de Cuiabá, realizada logo na altura do descobrimento das minas, para o que se deslocou até ao local o governador de São Paulo. A instituição da vila não só instaurava a legitimidade do poder administrativo sobre o espaço como também regulava, em termos sociais, a própria vivência naquele espaço que, sem as respectivas autoridades, tendia para o caos. Submetida, hierarquicamente, ao centro de poder instalado em São Paulo, a vila de Cuiabá transformava o Mato Grosso numa área reconhecida, mas periférica.

Quando se pôs em causa a capacidade de defesa do território, foi outra vez na criação de uma vila que se pensou. A instituição do novo município funcionaria como ação legitimadora da posse do espaço e a sua população serviria como potencial exército na defesa da região. No entanto, a dimensão política daquele espaço ultrapassava as circunstâncias de defesa de uma área localizada, para vir a significar a defesa de "toda" a conquista. Assim a área ganhou autonomia e, subvertendo a hierarquia a que estava submetida, passou a ter um governo próprio, em vez de ser governada a partir de outro ponto. Esta
5. Instruções passadas ao Governador D. António Rolim de Moura em 19 de Janeiro de 1749; apud Carlos Francisco de Moura (1982,p. 127-137). 
6. MINUTA da carta régia datada de 5 de Agosto de 1746 determinando a criação de uma nova vila no Mato Grosso.AHU Mato Grosso caixa 3 doc 2. Paulo F. Santos, em seu trabalho pioneiro sobre a formação de cidades no Brasil colonial, divulgou várias cartas de fundação de vilas que tinham todas o mesmo texto-padrão, similar ao que foi utilizado para a nova vila do Mato Grosso (cujo documento também é ali reproduzido na íntegra). Entre os exemplos citados encontram-se as vilas de Icó, Montemor e Aracati, no Ceará e Vila Boa de Goiás. Oeiras e outras vilas no Piauí foram também citadas na mesma obra, a partir das indicações já antes publicadas por Paulo Tedim Barreto. Cf. Paulo F. Santos (1968, p. 44 62); e Paulo Tedim Barreto (1938, p. 187-223).

7. Como observa Jaime Cortesão, "Individuar a prelazia de Cuiabá equivalia a tornar mais explícito o beneplácito da Santa Sé" para toda a conquista do Oeste; $c$ f.Jaime Cortesão (1984, p. 682). simples deslocação de centralidade alterou consideravelmente as hipóteses de gestão do espaço.

A nova vila, já determinada e prevista desde 1740 e para a qual se tinha feito uma carta régia determinando a sua criação em 17466, assumiria então o papel de capital da nascente região administrativa. Note-se que, em 1745, com o estabelecimento da prelazia de Cuiabá, dera-se um primeiro passo no sentido de dotar a região de uma individuação institucional que, sob certos aspectos, procurava garantir o reconhecimento internacional do direito de jurisdição sobre o território 7 . Tal situação, aliás, não é diferente do sucedido em 1676, quando Roma aceitou que o Rio da Prata fosse o limite do então criado bispado do Rio de Janeiro, admitindo, implicitamente, a legitimidade da jurisdição portuguesa até aquela área, o que viria a constituir mais um argumento para a criação, em 1680, da Colónia do Sacramento.

O que importa realçar é que, no Mato Grosso como em outras situações, o processo de incorporação progressiva do território sustentou-se sobre o estabelecimento de um suporte jurídico-institucional, no qual a vila detém um papel preponderante. Não se tratava apenas da instalação de mais povoados na área, pois o surgimento dos arraiais de mineração tinham, de algum modo, alargado o âmbito da ocupação física da região. A vila significava, acima de tudo, a ocupação política do território que, neste caso, se revestia de prioridade sobre a física. Assim, enquanto a primeira vila dera lugar jurídico ao caminho do Mato Grosso, vinculando aquele espaço ao centro de poder já existente, a segunda vila daria lugar jurídico à região em si, nela criando um novo centro de poder, uma capital, o que é relevante.

Nomeado em julho de 1748, D. António Rolim de Moura recebeu a sua carta patente em setembro do mesmo ano e, em janeiro do ano seguinte, as instruç̃ẽes para o governo da nova capitania. Partiu para o Brasil em fevereiro de 1749, acompanhado de uma companhia de dragões que vinha servir sob o seu comando. Aportou inicialmente no Recife, onde aguardou transporte para o Rio de Janeiro, para onde partiu em abril, chegando em junho. Em novembro de 1749, com toda a comitiva de dragões, seguiu para Santos e dali para São Paulo, onde chegaram em janeiro de 1750. Passaram-se ainda mais seis meses antes da partida definitiva para o Mato Grosso, tendo o novo governador a oportunidade de vistoriar o caminho até Araritaguaba, e de ir a Parati conferenciar com Gomes Freire de Andrade. A comitiva de Rolim de Moura partiu finalmente de Araritaguaba em 5 de agosto de 1750. Chegado a Cuiabá a 12 de janeiro de 1751, deu início ao governo autónomo do Mato Grosso.

Das vilas e dos rios

Em setembro deste mesmo ano de 1751, chegava a Belém Francisco Xavier de Mendonça Furtado, irmão de Sebastião José de Carvalho e Melo, que 
vinha como capitão-general e governador do estado e como plenipotenciário das demarcações no norte. A grande novidade que a chegada do 19 governador do estado trazia à cidade era a sua ascensão a capital do mesmo, ocupando o papel antes detido por São Luís.

Desde o século XVII, Belém reivindicava uma capitalidade natural sobre a bacia amazónica, que excluía São Luís. Era nesta qualidade, ou pretensão, de "capital da fluviocracia"8 que a cidade reclamava que os governadores deviam instalar-se ali e não em São Luís, e muitos o fizeram. Mas se é inegável que, comparada à São Luís, a situação de Belém representava uma efetiva centralidade em relação à bacia amazónica, a despeito da sua privilegiadíssima situação geográfica, não deixava de ser uma centralidade periférica, digamos, uma vez que era partir da foz que se pretendia atuar sobre todo o rio e, por extensão, sobre a bacia.

Tal facto é significativo, na medida em que esta relação correspondia de certo modo ao quadro da ocupação da Amazónia. Com efeito, as únicas quatro vilas existentes na região até a primeira metade do século XVIII localizavam-se todas relativamente próximas de Belém. No vastíssimo interior estavam algumas fortalezas e cerca de 70 estabelecimentos missionários, que incluíam os aldeamentos e as fazendas das missões. $\bigcirc$ estatuto desses aldeamentos missionários era algo ambíguo, posto que sua identificação não correspondia à mesma imagem para cada um dos grupos envolvidos. Aos olhos da coroa, representavam áreas de ação da soberania portuguesa, que confiara aos missionários a tarefa de converter os nativos à fé cristã. Para os colonos, as missões eram possivelmente vistas apenas como reservas de mão de obra, enquanto, quer para os missionários, quer para os índios, não eram seguramente isto, mas também não eram vilas, uma vez que pretendiam, de facto, ser diferentes delas.

A característica fundamental dos aldeamentos era a tutela dos missionários. Tutela essa julgada imprescindível para mediar as relações com os indígenas, que precisavam converter-se: à religião e à civilização. Neste sentido, os aldeamentos eram vistos como um espaço de transição - transição entre o mato e a cidade, entre o não urbano e o urbano. Mas eram vistos e entendidos como um elemento integrante do processo de ocupação.

Nas instruções régias recebidas por Mendonça Furtado constavam expressamente as seguintes determinações:

Recomendo-vos muito a extensão da cultura e povoação de todo este governo [...] e especialmente as missões do Cabo do Norte, onde cuidareis logo em estabelecer não só povoações, mas também defensa para fazer a barreira deste estado por esta parte, evitando por esta forma as desordens e conquistas que por esta parte the podem fazer os franceses e holandeses, para cujo fim mandareis missionários, executando-se sem demora nem admitir escusa a resolução que fui servido tomar a este respeito em 23 de julho de $1748^{9}$.
8. A expressão é de Eidorf Moreira (1960).

9. Cf. BNP Reservados Colecção Pombalina 626, fl. 17. 
10. Carta de Francisco Xavier de Mendonça Furtado a Diogo de Mendonça Corte Real datada de 25 de Janeiro de 1752; cf. Marcos Carneiro de Mendonça (1963, v. 1, p. 210-211).
A área do Cabo do Norte, que corresponde grosso modo ao atual estado do Amapá, era uma região disputada desde há muito, sobretudo pelos franceses. $\bigcirc$ tratado de Utrech, assinado em 1713, colocava a área na posse portuguesa, mas o perigo continuava a existir, posto que os portugueses tinham ali apenas um pequeno forte e um reduto, construído em 1738. Era esta a situação com que se deparou Mendonça Furtado e que merecia o tratamento de urgência requisitado pela coroa.

Neste sentido, uma das suas primeiras providencias no governo do estado foi enviar uma expedição com colonos açorianos para fundar a nova povoação e fortaleza de Macapá, que partiu de Belém em 19 de dezembro de 1751. No mesmo dia escrevia já o governador ao reino, dando conta do procedimento e afirmando o seu empenho em continuar o envio de casais e soldados.

Em janeiro de 1752, o seu relato apresentava assim a povoação:

Aquela povoação se fundou com a denominação, por ora, de São José de Macapá, enquanto S. Magde. não é servido declarar se quer seja cidade ou vila e o nome que deve ter. A mim me parecia que com o grande estabelecimento que tem podia S. Magde. fazer cidade, porque de primeiros povoadores há de ter perto de 600 pessoas brancas que, certamente, sem mescla, não as tem nenhuma deste estado, e em poucos anos me persuado que há de ser a mais florescente de todas, se acaso as comunidades os não forem conquistar e deixarem aquele pedaço de terra livre aos seculares, assim como tem sucedido até agora ${ }^{10}$.

Há dois aspectos a ter em conta neste trecho. Por um lado, o entusiasmo e cuidado de Mendonça Furtado na povoação de Macapá, que continuaria a manifestar-se ao longo do seu governo. Por outro, a animosidade para com os missionários, que também se revelará presente e crescente.

Mas o que sobretudo importa considerar é que esta ação urbanizadora que se realizou em Macapá continuava de certo modo o mesmo tipo de investimento que até então se tinha feito na região, concentrando a criação urbana na zona mais próxima da costa, desta feita, aliás, e finalmente, na verdadeira foz do rio Amazonas e, não à toa, na própria linha do Equador. Neste sentido, Macapá pode ser lida como uma espécie de reflexo especular de Belém, ambas garantindo a entrada do grande rio. De igual modo, o processo de criação urbana continuava a fazer uso dos casais das ithas que também tinham sido os povoadores chamados, desde o século XVII, para Belém e São Luís.

O mesmo pode também ser dito das duas seguintes iniciativas de Mendonça Furtado na criação de vilas na Amazónia, que são os casos de Bragança e Ourém. Em Bragança tratou-se de uma refundação, posto que feita na antiga Vila Sousa do Caeté, que fora estabelecida no século XVII por Álvaro de Sousa, donatário da capitania do Caeté. Por determinação régia, a capitania fora passada novamente para a Coroa. As opiniões sobre a Vila Sousa atestavam a sua decadência, e o investimento do governador em sua reconstrução e refundação imprimem-the nova vida. Também aqui instalaram-se casais açorianos 
enviados como povoadores. Mas o principal motivo do investimento era o caminho para o Maranhão, que se fazia com paragem naquela vila, e a sua manutenção, enquanto ponto de contacto entre as duas capitanias, era muito importante.

O encarregado da instalação de ambas as vilas foi o ouvidor João da Cruz Dinis Pinheiro, o mesmo que também tinha sido enviado em 1752 para o Macapá e que, desde aquele ano até a sua morte em 1757, seria o seu principal dinamizador. É interessante o papel desempenhado por Dinis Pinheiro. Em Macapá foi o responsável pela instalação e pela distribuição de lotes entre os povoadores e, nesse sentido, pelo desenho básico da povoação no terreno. Conhecem-se dois desenhos assinados pelo ouvidor em que se mostram as duas grandes praças que conformam o projeto do Macapá. Estas seriam depois redimensionadas e redesenhadas pelo engenheiro Tomás Rodrigues da Costa, que depois da morte de Dinis Pinheiro seria o responsável pela implementação da vila.

Em Bragança e Ourém, o ouvidor fez-se acompanhar de "astrológos e engenheiros" 11 . O plano das vilas foi por eles delineado, juntamente com o da nova estrada que as deveria ligar, e o desenho de ambas consta no mapa do caminho executado por Galluzi em $1754^{12}$.

No mesmo ano em que Mendonça Furtado deu início aos trabalhos de instalação de Macapá, Rolim de Moura fundava no Mato Grosso, em 19 de março de 1752, Vila Bela da Santíssima Trindade, a nova capital da capitania, que seria o ato central do seu governo. Também aqui teve especial importância o ouvidor Teotónio da Silva Gusmão que coadjuvou o governador na escolha do local para a instalação da capital (Figura 1).

Rolim de Moura procurou cumprir o mais escrupulosamente que pôde as determinações da carta régia que determinara a criação da vila. Começou precisamente pela praça, quadrada, orientada segundo os eixos cardeais, e dos seus ângulos fez partirem as ruas. Na praça elegeu um lado para a construção da residência do governador, outro para a igreja, outro para a câmara, e outro ainda para os quartéis. A recomendação seguinte da carta régia, que insistia para que se mantivesse o alinhamento das ruas, foi especialmente considerada. Num primeiro momento, não foi possível impor à pobreza dos moradores a simetria das fachadas, mas o governador esperava que esses pudessem, no futuro, fazer as suas casas todas iguais por fora, do modo a alcançar o ideal de beleza preconizado no documento ${ }^{13}$.

Mas, sobretudo, Rolim de Moura cumpriu a mais importante das determinações, que era instalar a nova vila e capital da capitania no rio Guaporé, de modo a garantir a reivindicação que a coroa portuguesa fazia daquele rio como limite entre as duas coroas.

Com efeito, pelos termos do Tratado de 1750, o Guaporé foi aceite como o limite entre os domínios português e castelhano, ficando os territórios a leste do rio para a Coroa de Portugal e os a oeste para a Espanha. Os jesuítas comprometiam-se, de maneira similar ao que se deveria passar também no Sul, a transferir para a margem ocidental do rio as aldeias de Santa Rosa, São Miguel e São Simão, fundadas na margem oriental respectivamente em 1742, 1744 e
11. Trata-se de F. A. Galluzi, Domingos Sambucetti e João Ângelo Bruneli.

12. Henrique Antonio Galluzi (1754).Arquivo Histórico do Exército, Rio de Janeiro. MIGI / 028.B3.

13. Carta de D.António Rolim de Moura ao Conselho Ultramarino. AHU Mato Grosso caixa 6 doc. 16 - 22 de Outubro de 1752 .. 


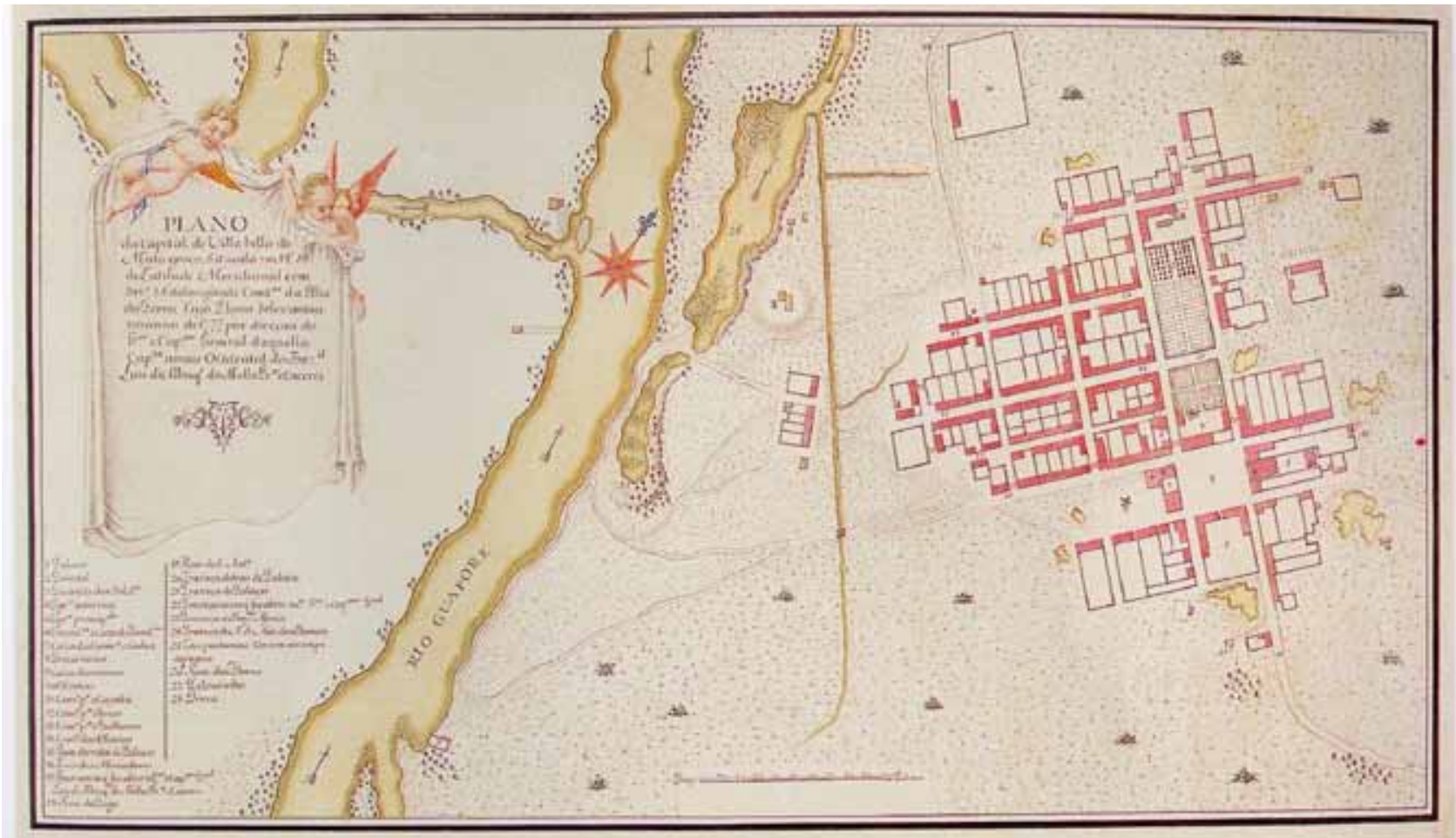

Figura 1 - Plano da Capital de Villa Bella do Matto grosso, situada em 1455' de Latitude Meridional em em $318^{\circ} 33$. de longitude Cont. ${ }^{S}$ da llha do Ferro; cujo Plano se levantou no anno d'1777 por direcção do Gov.or e Cap.am General daquella Cap. ta a mais Ocidental do Brasil. Luís d'Albuquerque d'Mello Pr. ${ }^{a}$ e Cáceres no anno XVIII do seu felis governo. Manuscrito. Casa da Ínsua, cota n 5 (Garcia, 2002: 178-179)

1746. A navegação no rio estaria garantida para ambos os litigantes, assegurando-se para os portugueses a tão pretendida comunicação com o Pará. No entanto, embora as condições tivessem ficado definidas no Tratado, nada se fez, de ambos os lados, para mudar a situação existente na região: os jesuítas não saíram das aldeias, e a coroa portuguesa não abriu o "caminho" do Guaporé, até 1752.

A questão da abertura, ou não, da navegação do Guaporé foi discutida na metrópole e na colónia, e os pareceres suscitados eram os mais diversos. Mantinham-se os temores quanto aos perigos que o alargado conhecimento das comunicações pudesse provocar, tanto pela parte dos espanhóis, como dos próprios colonos portugueses. Temia-se que, por aquele meio, fossem divulgados os segredos da navegação interior da Amazónia, pondo em risco a colonização do Norte. Mas era especialmente o receio do contrabando e do desvio do ouro o que continuava a assustar os portugueses e a sustentar os discursos contra a abertura de um novo caminho para as minas. Em meio à polémica gerada, havia, inclusive, quem argumentasse que a navegação do Guaporé poria em risco a alfândega do Rio de Janeiro, que perderia parte das suas receitas, pois as mercadorias passariam a ser introduzidas nos sertões através 
do Pará ${ }^{14}$. Este argumento é importante, pois revela o quanto pesavam na gestão da colónia as questões relativas ao controle dos portos na costa atlântica, concentrando efetivamente ali as atenções da coroa.

D. António Rolim de Moura era um ardoroso defensor da abertura oficial do caminho do Guaporé, sustentando que dali dependeria todo o sucesso da instalação da nova vila e, consequentemente, a própria manutenção da capitania. O Mato Grosso e, especialmente, a nova vila, necessitavam de ser abastecidos e, de facto, a comunicação pela bacia amazónica era bastante mais rápida e viável para aquela vila do que o caminho de São Paulo, que servia especialmente a Cuiabá. $\bigcirc$ governador garantia que, além de mais rápido, era também mais seguro, pois o único perigo na região do Madeira eram os índios Mura, que não atacavam nos rios com o mesmo ímpeto dos Payaguás, que ainda causavam grandes problemas às monções ${ }^{15}$.

Francisco Xavier de Mendonça Furtado também defendia a navegação do Guaporé como o único meio de garantir a defesa da região, argumentando que o facto de serem os portugueses proibidos de utilizar aquele caminho não impediria os espanhóis de o fazerem, muito pelo contrário. Neste sentido, descuidar o caminho era certamente, mais perigoso do que o frequentar.

Assim, após a efetiva fundação e instalação de Vila Bela, franqueou-se a navegação do Guaporé, que foi oficialmente autorizada em outubro de 1752. Na mesma altura, os jesuítas castelhanos finalmente abandonaram as aldeias de Santa Rosa, São Miguel e São Simão, transferindo-as para margem ocidental do rio. A primeira a ser evacuada foi a aldeia de São Simão, nos finais de 1752, e a seguir São Miguel e Santa Rosa, entre 1753 e 1754. Os sítios das antigas aldeias foram queimados, mas o padres mantinham em algumas delas campos de cultivo que continuaram a ser visitados pelos índios.

A urbanização do mato

Em 1752 tinham também começado, no Sul, as demarcações previstas pelo Tratado de Madrid. Os plenipotenciários português e espanhol, respectivamente Gomes Freire de Andrade e o marquês de Valdelirios, deram início aos trabalhos da primeira partida demarcatória no dia 18 de outubro de 1752. No entanto, como sabemos, em março de 1753, iniciaram-se as hostilidades entre os índios das missões jesuíticas e os exércitos português e castelhano, dando origem à famosa guerra guaranítica, que iria durar até 1756 . A conjuntura no Sul era tensa.

A conjuntura no Norte não era menos tensa que no Sul. Em 1753, tinham chegado a Belém os engenheiros e astrónomos da comissão demarcadora de limites e, em 1754, Mendonça Furtado partira com eles para a aldeia carmelita de Mariuá, no rio Negro, onde foi decidido que se realizariam as conferências entre as comissões portuguesa e espanhola. Esteve o governador e
14. Para uma síntese das discussões acerca a abertura do caminho do rio Guaporé veja-se Marcos Carneiro de Mendonça (1961, p. 3-32), onde são publicados trechos da correspondência de Francisco Xavier de Mendonça Furtado e de Sebastião José de Carvalho e Melo sobre o assunto. Várias cartas trocadas entre Francisco Xavier de Mendonça Furtado e D. António Rolim de Moura também abordam a mesma problemática. Ver BNP Colecção Pombalina cod. 629.

15. CONSULTA régia sobre abertura do caminho do Guaporé com carta de D. António Rolim de Moura ao Conselho.AHU Mato Grosso caixa 6 doc 61 - 26 de Maio de 1753 . 
plenipotenciário sediado no rio Negro por cerca de quatro anos, coordenando os trabalhos de levantamento dos rios e à espera dos espanhóis, mas o encontro previsto não ocorreu.

Entretanto cresciam as tensões internas envolvendo os colonos e os missionários. $\bigcirc$ cerne dos conflitos, que duravam desde o início da colonização da Amazónia, centrava-se na gestão da distribuição da mão de obra indígena. Mas as relações se tinham sobretudo agravado perante o clima de desconfiança relativamente à lealdade dos missionários nas questões territoriais, em especial os jesuítas, invocando-se como exemplos o episódio da revolta dos índios nas missões guaranis e a proximidade do caso das aldeias no rio Guaporé.

Tais factos devem ser levados em consideração para melhor enquadrar as medidas tomadas por Mendonça Furtado entre 1755 e 1759. Indissociáveis e definidas num mesmo bloco, tais medidas foram as bases em que se sustentou uma verdadeira transformação do quadro urbano da Amazónia e cujas consequências para o conjunto do território brasileiro são especialmente significativas.

A mais importante delas foi a lei que abolia todas as formas, até então em vigor, de cativeiro dos naturais, que foi promulgada em 6 de junho de 1755, e vinha associada a outro alvará, assinado no dia seguinte, retirando o domínio temporal dos missionários sobre os índios e determinando que passassem a vilas as aldeias que tivessem competente número de gente. No mesmo dia 7 de junho, foi também publicado o Alvará régio de confirmação da instituição da Companhia de Comércio do Grão-Pará e Maranhão, que tinha sido levado à aprovação no dia anterior.

A liberdade dos índios fazia parte das medidas prioritárias do programa de governo de Francisco Xavier de Mendonça Furtado e vinha já determinada nas orientações que trouxera do Reino. Era uma medida realmente importante, tanto no sentido de resolver a disputa de poder com os missionários, como no interesse da preservação das fronteiras definidas no acordos, que exigiam uma situação pacífica e aliada aos naturais da terra. Embora estivesse determinado a implementar a liberdade, o governador, ciente da grave situação que a medida geraria na colónia, teve de esperar para pô-la em prática. Fê-lo dentro do contexło da criação da Companhia, usando a introdução da escravatura africana como argumento para amainar os ânimos dos colonos.

A Companhia, protegida pelos privilégios do monopólio, obrigar-se-ia ao transporte dos africanos e à sua venda aos colonos do Pará e do Mato Grosso, o que é significativo e esclarece o quão importante fora, também em termos económicos, a decisão de abrir o dito caminho de comunicação fluvial entre o Pará e o Mato Grosso. A proibição do cativeiro dos indígenas impunha a interrupção da sua utilização como mão de obra. Assim, ao mesmo tempo que se obrigava o investimento nos escravos africanos, fazendo com isso ganhar a Companhia, desferia-se um rude golpe no poder detido pelos missionários, que deixavam de poder gerir a distribuição dos trabalhadores, como até então faziam. Do mesmo modo, a determinação de cessar totalmente o seu poder temporal 
sobre os naturais impedia-os também de manter qualquer tentativa de influência nos próprios índios.

Tal política foi posta em prática, apesar dos protestos que se seguiram à instalação de ambas as medidas. Tanto da parte dos missionários, que se sentiam claramente lesados, como da parte dos colonos, que temiam a novidade, pelas dificuldades financeiras que logo de início se thes apresentavam e que, de resto, viriam a pôr em causa a própria sustentabilidade da Companhia a longo prazo.

Neste mesmo ano, e ainda antes da promulgação da lei da liberdade, duas outras cartas régias tinham sido assinadas, ambas no dia 3 de março de 1755. Numa criava-se a capitania de São José do Rio Negro, desmembrando-a da grande capitania do Grão-Pará e, no mesmo documento, determinava-se a criação de uma nova vila para a sediar. Na outra carta determinava-se a criação de outra vila na nova capitania que se chamaria Borba-a-Nova, a ser erigida na aldeia do Trocano no rio Madeira.

A decisão de criar uma nova capitania, justifica-se na própria carta régia com as seguintes palavras:

Tendo em consideração ao muito que convém ao serviço de Deus e meu, e do bem comum dos meus vassalos moradores nesse estado, que nele se aumente o numero dos fieis alumiados das leis do Evangelho, pelo próprio meio da multiplicação das povoações civis e decorosas; para que atraindo a si os racionais, que vivem nos vastos sertões do mesmo estado, separados da nossa santa fé católica e até dos ditames da mesma natureza, e achando algum deles na observância das leis divinas e humanas socorro e descanso temporal e eterno, sirvam de estímulo aos mais que ficarem nos matos para que, imitando tão saudáveis exemplos, busquem os mesmos benefícios e atendendo a que aquela observância da lei se não conseguirá para produzir tão úteis efeitos, se a vastidão do mesmo estado, que tanto dificulta os recursos às duas capitanias do Grão-Pará e Maranhão se não se subdividisse em mais alguns governos a que as partes possam requerer para conseguirem que se lhes administre justiça com maior brevidade e sem a vexação de serem obrigados a fazer tão longas e penosas viagens, como agora fazem ${ }^{16}$.

Note-se que a decisão de criar uma nova capitania insere-se num quadro similar ao da criação da capitania do Mato Grosso. Embora o texto não refira explicitamente, parte fundamental da medida deve-se às preocupações com a defesa da região e a conjuntura das demarcações. De igual modo, a decisão de estabelecer uma nova vila para sediar a capital segue também os mesmos preceitos já utilizados no Mato Grosso. Embora se tenha depois reconsiderado, determinou-se que a localização da nova vila se fizesse precisamente na fronteira, tal como em Vila Bela. Assim como também se repetiram os termos da carta de privilégios concedidos aos moradores da capital do Mato Grosso e as mesmas recomendações relativas à instalação formal do núcleo.

Este último aspecto é significativo e cabe chamar a atenção para a continuidade da política de criação urbana iniciada ainda no reinado de D. João $V$, que vinha fazendo uso destas cartas régias de fundação de vilas. Mas importa 
17. Horta Correia reforça o carácter moderno do formulário das "cartas de fundação" utilizadas no Brasil "Estão aqui portanto, os princípios essenciais do urbanismo da época moderna: a linearidade, a uniformidade e o programa. E este último, pelo menos, é digno de nota pelo seu vanguardismo."; cf. José Eduardo Horta Correia (1995, p. 105).

18. CARTA familiar e secretíssima em resposta das que havia recebido nas datas do mes de Novembro de $1752 \ldots$ BNP Reservados cod. 11393, f. 89-105 [Cópias de cartas do Parál. sobretudo, como já se disse noutras ocasiões, valorizar o próprio conteúdo programático das cartas, que pode ser lido como uma espécie de metodologia de desenho urbano e, em especial, o ideal estético implícito no texto, sintetizado na expressão "formosura da terra"17. A ideia do urbano preconizada nestes documentos é a das ditas povoações civis e decorosas, das quais se esperava que não só atraíssem a si os indígenas, como servissem de estímulo aos mais que estavam nos matos.

Estas expressões não são muito diferentes das que constavam numa carta secretíssima de Sebastião José de Carvalho e Melo, escrita ainda em 1753, na qual diz a Mendonça Furtado que era conveniente fazerem-se vilas que também deveriam ser chamarizes para os índios. A instrução precisa de Pombal era que

fomentando-se a vaidade natural dos mais poderosos destes americanos, ou com a esperança de honorífico senhorio das vilas que fundardes ou com outras honras que sejam indiferentes, por uma parte hirão insensivelmente dezaparecendo as Aldeyas que devem abolir-se, porque os índios, vendo-se nelas tiranizados e vendo-se nas outras povoações favorecidos, he certo, que fugindo das primeiras encherão dentro em pouco tempo as segundas. Por outra parte se hirão multiplicando, e florescendo povoações civiz, decorosas e úteis para o bem Comum da Coroa e dos Povos ${ }^{18}$.

Tendo naturalmente em conta os conselhos recebidos, a ação de Mendonça Furtado será contudo bem mais incisiva e direta que a sugerida pelo irmão. A sua atuação vai adiantar-se ao subtil plano de insensivelmente fazer desaparecer as aldeias pela atração de outros núcleos e vai investir na reconversão dos próprios aldeamentos que serão elevados a vilas.

Com efeito, e tal como dizíamos antes, a existência dos aldeamentos implicava um cenário de certo modo dividido na ocupação do território. Os aldeamentos eram vistos como um espaço de transição entre o mato e a cidade. Entendiam-se como parte do processo de ocupação do território e implicavam, no fundo, a leitura diferenciada do espaço dos índios (o mato) e o espaço dos colonizadores (a cidade). Em princípio, e simbolicamente, a cidade iria, gradualmente, dominar o mato. A percepção in loco que o governador teve do quadro regional ter-the-á feito ver que esta leitura processual não se aplicava. Segundo a sua visão, a existência em si dos aldeamentos implicava, na prática, um domínio dividido do território, não entre os índios e os colonizadores, mas entre a coroa e as missões.

Neste sentido, a sua ação converge para anulação dessa divisão implícita. E o processo utilizado para a unificação do espaço é a literal urbanização do mato. A ideia que norteia a sua ação é precisamente a que está subjacente ao ideário iluminista, a da cidade, per se, pela sua forma e função, como espelho de civilização, a cidade demiurga, capaz de mudar a natureza e os povos. E com esta ideia, da urbanidade como elemento civilizacional, pretende transformar o mato. Mais ainda, pretende também, e assumidamente, garantir o 
domínio do mato, isto é, do território que ele implicava. Como dizia o irmão, dever-se-iam fazer povoações úteis para o bem comum da coroa e dos povos.

Consciente da impossibilidade de abolir a diferença de leitura entre o aldeamento e a vila, Mendonça Furtado opta por abolir o próprio aldeamento. Este aspecto é fundamental porque implica numa consciência alargada de que o domínio do território da colónia não mais podia prescindir da efetiva integração dos seus naturais, precisava contar com eles como parte do próprio território e não mais como uma fronteira móvel continuamente mantida como zona de conquista. No entanto, tendo em conta a dificuldade em abdicar da tutela que os missionários representavam, ou a própria necessidade de os substituir nas tarefas de mediação, Mendonça Furtado vai criar uma legislação específica para o processo. Em 3 de maio de 1757, o governador torna público o instrumento legal que the permitiria mudar completamente o quadro urbano e social da Amazónia. A nova peça, que viria a ser confirmada pelo rei em 17 agosto de 1758, era o Directorio que se deve observar nas povoações de Índios do Pará e Maranhão ${ }^{19}$

Em síntese, o que ali se propunha era, na sequência da legislação já aprovada da liberdade dos índios, a cessação total e completa do poder temporal dos missionários sobre os nativos. Excluídos os missionários do governo, todos os aldeamentos que tivessem população suficiente deveriam ser elevados a vila, com a consequente instituição de um administrador em cada vila, o diretor. E era sobre a atuação deste diretor que se legislava e que se instituíam os meios com os quais se deveria obter a civilidade pretendida, para os índios e para os colonos.

Entre as determinações expressas na lei, constava que se deveriam extinguir totalmente as distinções existentes entre brancos e índios. Mais ainda, afirmava-se que "entre os meios, mais proporcionados para se conseguir tão virtuoso, útil, e santo fim, nenhum he mais efficaz, que procurar por via de casamentos esta importantíssima união ${ }^{20}$. Recomendava-se, assim, que se facilitassem os meios para que tais casamentos mestiços se pudessem realizar, afirmando explicitamente que

deste modo acabarão de compreender os Índios com toda a evidência, que estimamos as sua pessoas; que não desprezamos as suas alianças, e o seu parentesco; que reputamos, como próprias as suas utilidades; e que desejamos, cordial, e sinceramente, conservar com elles aquella recíproca união, em que se firma, e estabelece a sólida felicidade das Repúblicas ${ }^{21}$.

Nas novas vilas então criadas, índios e brancos não só deveriam viver em pacífica e cordial convivência como se recomendava expressamente que esta convivência redundasse numa progressiva miscigenação incentivando-se os casamentos mistos. Os vassalos do rei eram uns e outros, e os seus filhos.

A este ideal urbano de convivência civilizada correspondia, naturalmente, uma ideia de cidade também ela coerente e bem desenhada. No próprio Directório fazem-se algumas recomendações para o ordenamento urbano afirmando ser "evidentemente certo que para o augmento das povoações concorre muito a
20. Ibidem.

21. Ibidem. 
nobreza dos edifícios" 22 . Note-se que a ação é norteada por um sentido discursivo do urbano, que é valorizado quer enquanto linguagem estética - através da mensagem de beleza e nobreza da arquitetura e do desenho urbano -, quer enquanto linguagem ética - através do mecanismo de "suave persuasão", que se pretende obter pela coerência entre a clareza das formas e a nobreza das intenções.

Dado especialmente importante é o facto de que, quando o Diretório foi oficialmente promulgado em forma de lei, boa parte da conversão dos aldeamentos em vilas tinha já sido executada. De facto, as determinações para essa transformação vinham já indicadas na lei de liberdade dos índios, de 6 de junho de 1755. Em 1756, foi elevado a vila, com o nome de Borba-a-Nova, o aldeamento jesuíta dos índios Trocano no rio Madeira. Era o primeiro, para dar o exemplo e para salvaguardar o controle do caminho fluvial do Madeira-Mamoré. Entre o final de 1757 e o inicio de 1758, o governador, pessoalmente, procedeu a 25 elevações de aldeamentos a vilas. Outros membros da administração do estado participaram do processo, dando-lhe continuidade: o bispo D. Frei Miguel de Bulhões, o desembargador Pascoal Madeira, o ouvidor João da Cruz Dinis Pinheiro, e o governador da capitania do Rio Negro Joaquim de Melo e Povoas. No total, entre 1754 e 1759, quando termina o governo de Mendonça Furtado, instituíram-se 40 novas vilas e 31 lugares ou freguesias (Figura 2).

Em termos formais, os tipos de intervenção realizada nos aldeamentos variaram. Na maioria dos casos ter-se-ão mantido as infraestruturas já existentes, feitas pelos missionários. Mas, em outras circunstâncias, fizeram-se projetos

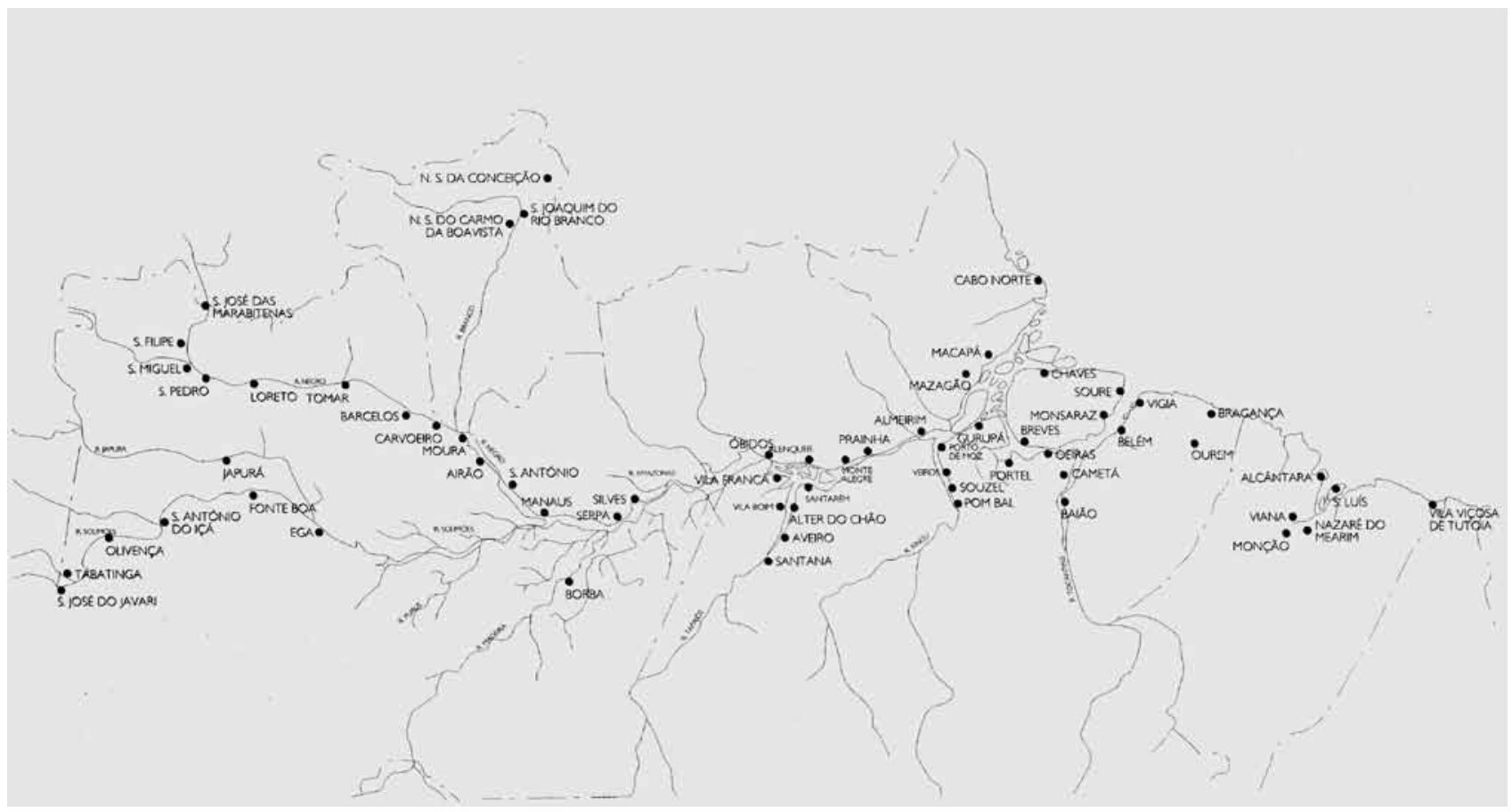

Figura 2 - Vilas e povoações criadas na Amazónia no século XVIII. 
específicos para as novas vilas, que foram idealizados pelos engenheiros da comissão demarcadora de limites, entre os quais, cabe citar o caso de Barcelos.

A vila foi criada a partir da reconversão da antiga aldeia de Marivá, dos missionários carmelitas, no rio Negro. Barcelos foi eleita para ser a capital da nova capitania do Rio Negro e foi também o local escolhido para a realização das conferências entre as duas comissões demarcadoras. $O$ espaço da vila foi palco de diversas intervenções urbanísticas feitas pelo engenheiro militar Filipe Sturm.

Filipe Sturm é também o autor de três outros projetos muito significativos. Em São José das Marabitenas, o engenheiro delineou a fortaleza e a pequena vila adjacente, num projeto que tem uma coerência proporcional impar. Nos desenhos que realizou para as vilas de Serpa e Silves, é visível a base de planeamento militar. Para Serpa, o engenheiro propôs um hexágono regular, fazendo a vila literalmente na forma de uma fortaleza. Para Silves, o plano apresentado prevê uma vila com duas grandes praças retangulares que tem inequívocas relações com o grande projeto então em execução em Macapá (Figuras 3 e 4).

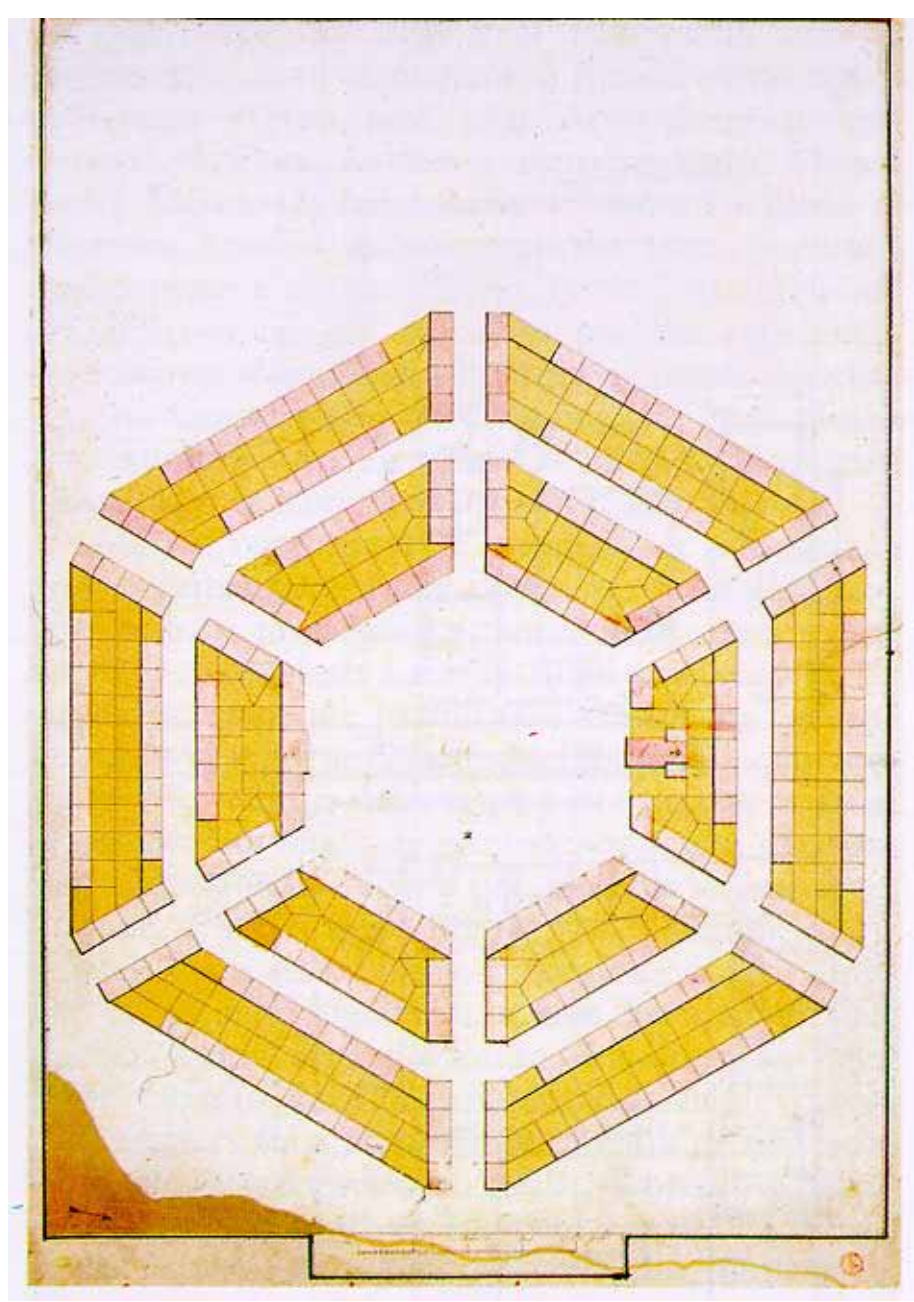

Figura 3 - Filipe Sturm, Planta da Villa de Serpa erigida pello Illmo e Exmo Snr Joaquim de Mello e Povoas Gov.dor desta Cap.nia. Porj. e Deliniada pello Captam Ing. Philippe Sturm. Manuscrito. Biblioteca Nacional, Lisboa, Iconografia D 201 A. 


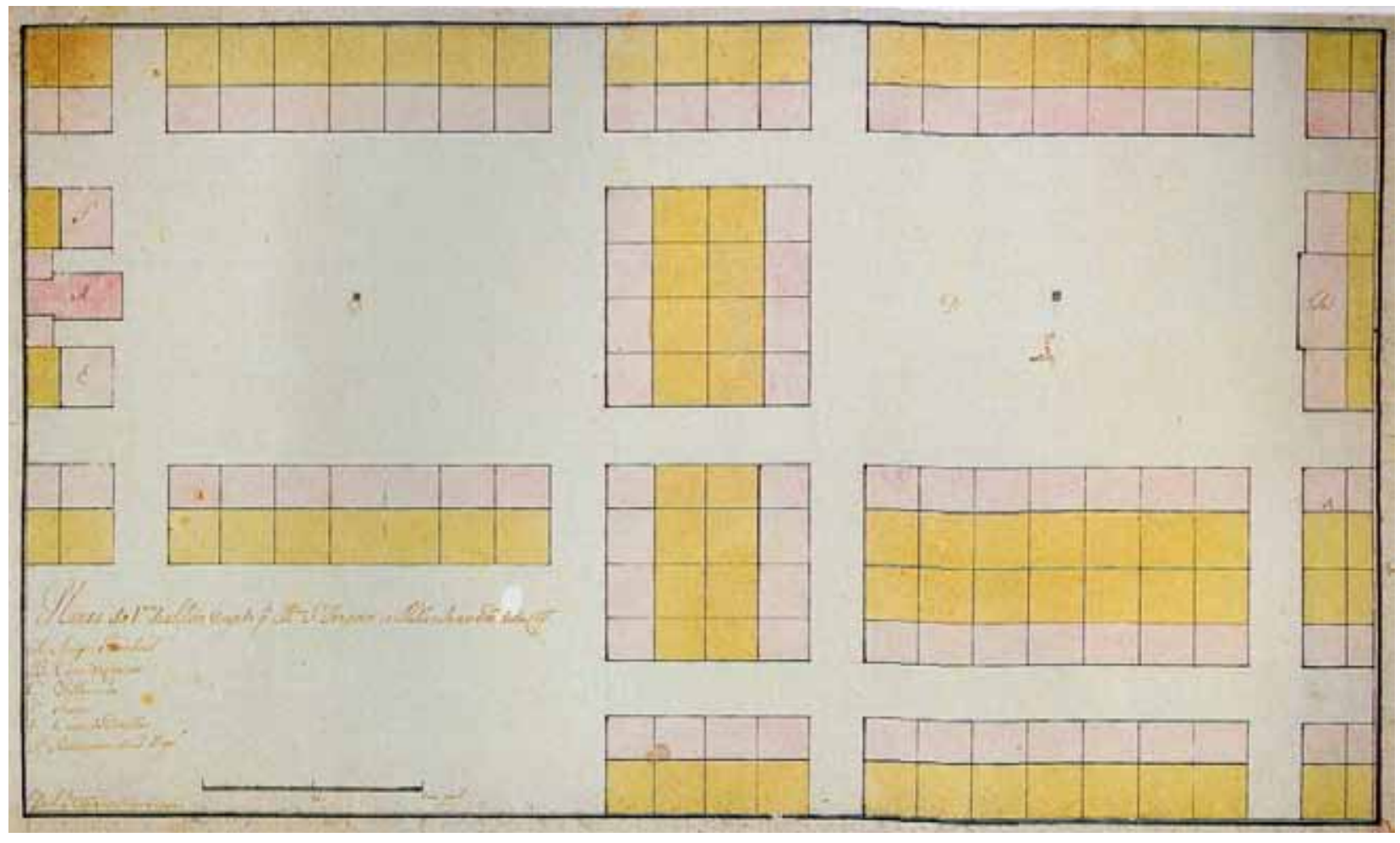

Figura 4 - Filipe Sturm, Planta da V.a de Silvez erigida pello Illmo Snr Joaquim de Mello e Povoas Gov. dor desta Cap.nia. Del. pello Captam Ing. Philippe Sturm. Manuscrito. Biblioteca Nacional, Lisboa, Iconografia D 199A.

São José de Macapá foi sem dúvida o grande empreendimento urbano de Mendonça Furtado - era a experiência-modelo que deveria espelhar o seu projeto administrativo e político. A criação da vila fez-se acompanhar de um projeto económico que se fundamentava no incentivo à agricultura e à pecuária (feito inclusive com doação de gados bovinos e equinos para os colonos), assim como no fomento à industria, em especial a fabricação de algodão, e a uma tentativa de criação de bichos-da-seda. E o projeto interno da vila também foi pensado ao pormenor pelo engenheiro Tomas Rodrigues da Costa, que desenhou a igreja, a câmara e o modelo das casas dos moradores, que deveriam ser todas iguais. Um código de posturas municipais viria reforçar este sentido da beleza da regularidade das fachadas, que deveriam ser mantidas pelos moradores. $\bigcirc$ discurso da civilidade pretendida era dado pela forma regular e bela da vila. $\bigcirc$ discurso da legitimação e do poder que a instituíra era feito no nome da vila de São José, em clara alusão ao rei, assim como no nome das duas grandes praças, de São João e de São Sebastião, que homenageavam o rei anterior e o ministro de D. José, irmão de Mendonça Furtado (Figura 5).

Importa referir que a escolha de Mendonça Furtado para os nomes das novas vilas não foi aleatório e seguiu critérios precisos de homenagem. Em ordem hierárquica de tamanho ou de importância geográfica, as novas vilas na selva 


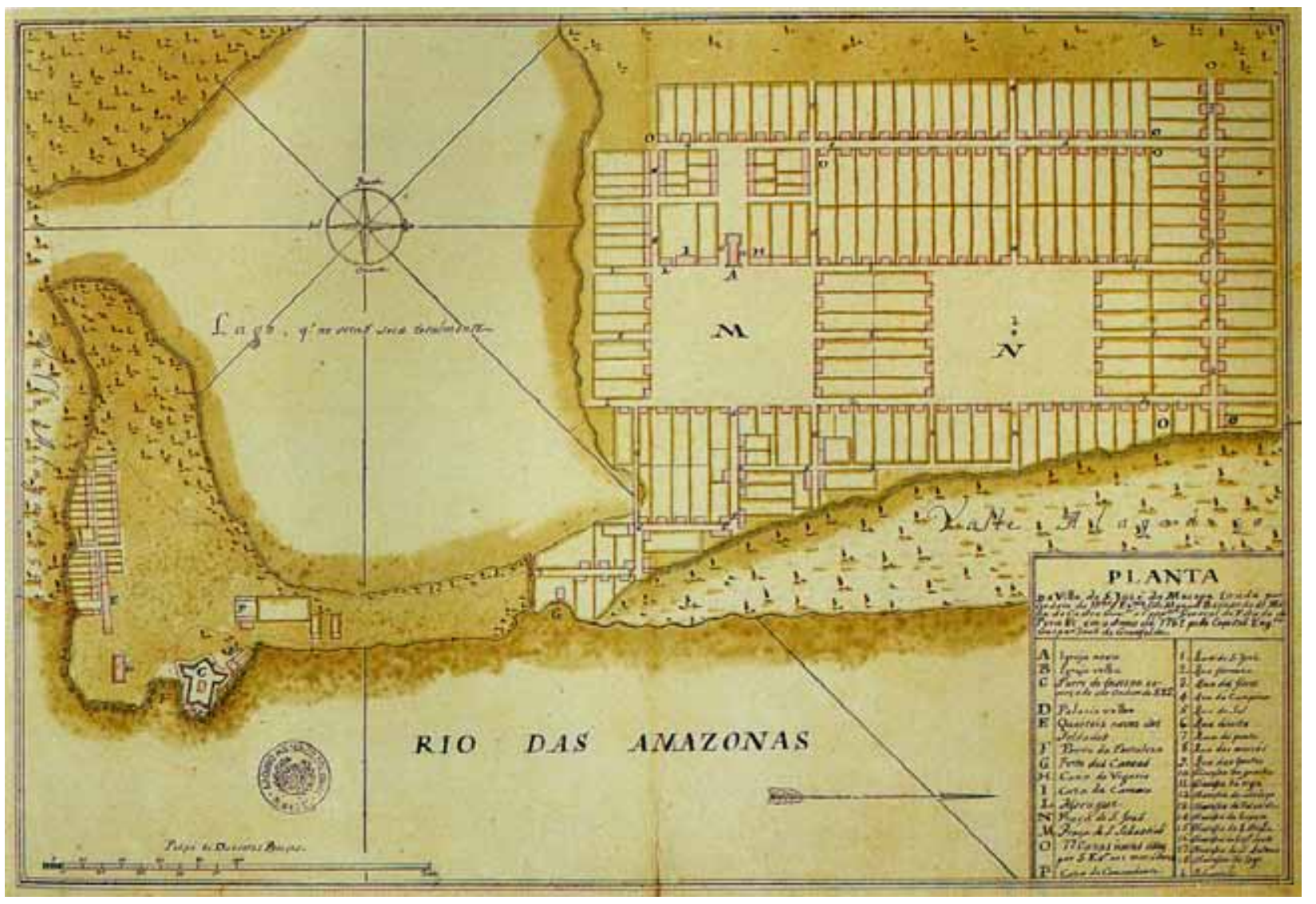

Figura 5 - Gaspar João de Gronsfeld, Planta da Vila de S. José de Macapá tirada por ordem do llmo e Exmo Sbr Manoel Bernardo de Mello e Castro Gov.or e Capp.am General do Estado do Para \& em o Anno de 1761 pello Capitão Eng.ro Gaspar João de Gronsfeld. (AHU Cartografia manuscrita Pará 789)

foram recebendo os mesmos nomes de vilas e cidades de Portugal ligadas à Coroa $^{23}$. Esta duplicação toponímica tinha como intenção óbvia reafirmar a pertença destas vilas a um espaço que se queria inquestionavelmente português. Mas seria também uma alegoria expressiva do projeto civilizacional e civil que elas deveriam espelhar, que invocava os exemplos dos mais antigos e tradicionais municípios do Reino. Para além disso, tal conversão toponímica visava deliberadamente eliminar os nomes indígenas dos antigos aldeamentos, para, no fundo, eliminá-los como conceito, substituindo-o pelo das vilas.

Mas, ao mesmo tempo em que as novas vilas da Amazônia evocavam o paradigma da urbanidade, a legislação do diretório não as dotava do mesmo mecanismo de gestão das outras vilas, porque implicitamente, e expressamente, achava que seus povoadores não estavam capazes de se governar sozinhos. Com o diretor, que era nomeado pelo governador, passava-se por cima da câmara, que é o órgão deliberativo e de representação do município. Assim, a figura do diretor é, em si, uma contradição e ao mesmo tempo a demonstração do enorme

23. CARTA de Francisco Xavier de Mendonça Furtado a Tome Joaquim da Costa Corte Real. "Para denominação das novas vila segui o systema de primeiramente extinguir os nomes das vilas da Real casa de Bragança, que me lembrarão, logo alguas da Coroa, e imediatamente as das terras da Rainha Nossa Senhora, alguas do Infantado, e ultimamente as da Ordem de Cristo, de quem são os dízimos de todas estas conquistas." BNP Colecção Pombalina 159 , f. $51 \mathrm{v}-13$ de Junho de 1757

Annals of Museu Paulista. v. 20. n.1. Jan.-Jun. 2012. 
24. Ver Henrique António Galluzi (1759). Original BNRJ. pragmatismo e da peculiar adaptabilidade do projeto colonial português. Poderse-á dizer que, nesse sentido, as novas vilas eram, de certo modo, falsas vilas, se as olharmos do ponto de vista da representação social.

Note-se que vários dos mecanismos que faziam parte do sistema dos aldeamentos continuaram a ser mantidos, inclusive os descimentos de índios para aumento da população das vilas. Neste caso os diretores é que eram incentivados a atrair novos povoadores para as suas vilas, aliciando-os, ou arrecadando-os, tal como os missionários faziam. O sistema de distribuição de mão de obra também continuou, ainda maior e mais complexo, o que em vários aspectos agravou a situação social que se pretendia resolver.

Mas não eram falsas vilas do ponto de vista da leitura do território. Ao contrário, o que a legislação de Mendonça Furtado fez foi trazer para o centro de administração da coroa a efetiva gestão territorial daqueles núcleos de povoamento, inserindo-os na sua toponímia e hierarquização específica. Veja-se, sob este ângulo, o quão importante é a questão do efetivo estabelecimento das freguesias, substituindo o espaço extraparoquial que os missionários tinham nas missões, onde não queriam inclusive receber os visitadores do bispado, o que reforçava esta leitura de um espaço diferenciado. Do que Mendonça Furtado se apercebeu é que tal distinção punha em causa o espaço do rei, em seu sentido mais amplo. Não era só a autonomia do poder real sobre a igreja o que estava em causa, mas o próprio espaço, que precisa ser reivindicado como domínio da coroa e que a conjuntura das demarcações de limites bem explicita.

Cabe por isso chamar a atenção, no conjunto da farta documentação cartográfica produzida na Amazónia nesse período, para um mapa em especial, - Mapa geral do Bispado do Pará repartido nas suas freguesias 24 (Figura 6). Esse mapa demonstra o verdadeiro sentido da reforma urbana de Mendonça Furtado. É raro, na cartografia do Brasil, as freguesias aparecerem delimitadas. No mapa, elas representam de facto cada um dos novos municípios recém-criados que se

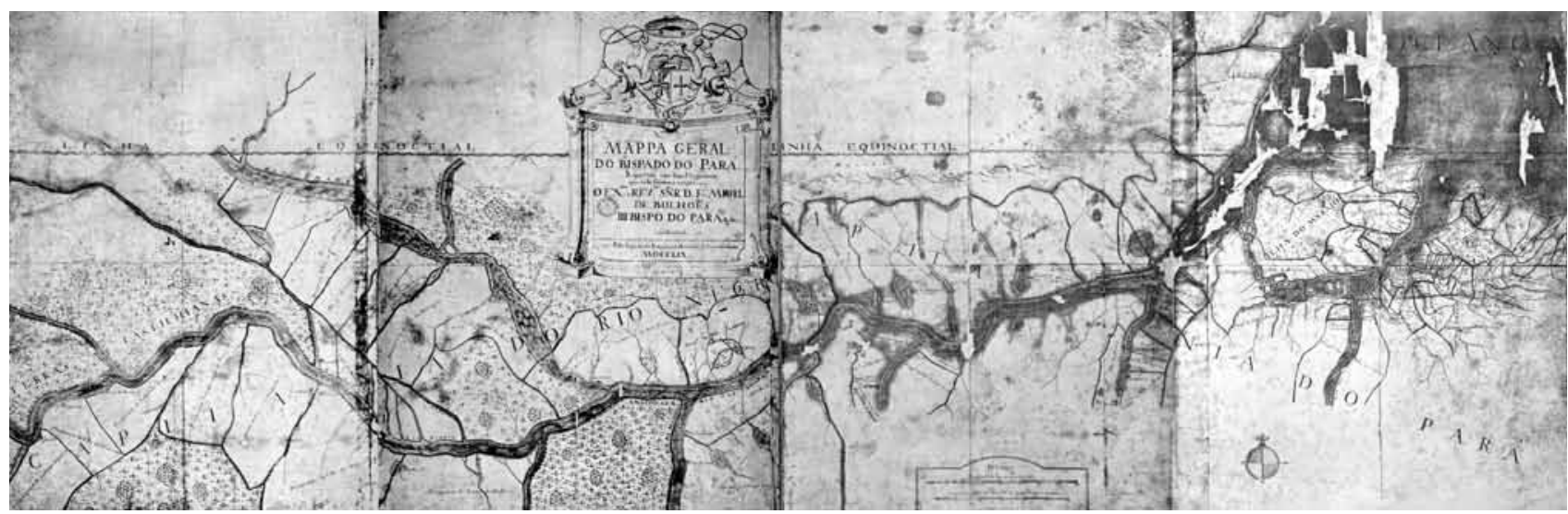

Figura 6- Henrique Antonio Galluzi, Mapa Geral do Bispado do Pará repartido nas suas freguesias, que nelle fundou e erigio o Exmo. E Rev.mo Snr D. Fr. Miguel de Bulhões, III Bispo do Pará \& construído e reduzido as regras da geografia com observações geomátricas e astronómicas pelo Ajudante Engenheiro Henrique António Galluzi, 1759. Original BNRJ. 
distribuem ao longo do rio Amazonas e de seus afluentes. Revela-se, na imagem, a clara urbanização do mato, do rio. Uma urbanização profundamente simbólica, que virtualmente se incorpora ao território, pois o lê, finalmente, no seu todo, como o espaço das cidades, abolindo desta feita o mato, ou o sertão, o lugar do não urbano, que por muito tempo ocupou o imaginário do território colonial.

É por isso especialmente significativo ver que a legislação gizada por Mendonça Furtado para o ambiente amazónico tenha sido, logo a seguir, aplicada em todo o Brasil, obrigando a que todos os aldeamentos missionários fossem elevados a vilas, seguindo as determinações do Directório dos índios aplicado no Pará ${ }^{25}$. Era a compreensão de que, em escala territorial mais vasta, havia necessidade de urbanizar os sertões para efetivamente os incorporar.

Neste âmbito, é importante referir a ação concertada de criação de vilas que se fez na capitania do Piauí, o que deve ser inserido no mesmo quadro de reforma territorial e urbana levado a cabo pela administração pombalina na Amazónia.

Ao longo da primeira metade do século XVIII, algumas ações foram tentadas para a estabilização e pacificação dos sesmeiros, que ali tinham sobretudo fazendas de gado, e dos indígenas, que em mais de uma ocasião revoltaram-se, pondo em causa a segurança da ligação do Maranhão com a Bahia. Mas será no âmbito da administração pombalina e sob a tutela de Mendonça Furtado que se vai efetivamente criar, em 1758, o governo autónomo da capitania do Piauí. João Pereira Caldas, o primeiro governador, começou seu governo em 1759. A decisão vem na sequência da criação, em 1755, da capitania do Rio Negro e justifica-se pela mesma necessidade de estabelecer uma gestão direta da área. Mas, na capitania do Piauí, o mais interessante é que a metodologia utilizada conjuga de maneira concertada a ação cartográfica de levantamento da capitania com a criação de novas vilas, que foram feitas tendo em conta a leitura global do território. Para tal importa referir outro elemento cartográfico crucial que é o Mappa Geographico da capitania do Piauhi... delineado por Henriques António Galucio em 1760, e, sobretudo, ao conjunto de cartas régias emitidas em 1761 para a elevação da vila de Mocha à capital da capitania, com nome de Oeiras, e para a criação de novas vilas em cada uma das freguesias da capitania.

Do deserto para selva

Francisco Xavier de Mendonça Furtado regressou para Portugal em 1759. No ano seguinte, assumiu a Secretaria de Estado da Marinha e Ultramar. É nesta condição de ministro da coroa que vai tomar ainda uma última decisão relativa à urbanização da Amazónia.

Por carta de 16 de março de 1769, Fernando da Costa de Ataíde e Teive, o governador do Grão-Pará, foi informado por Francisco Xavier de
25. O Directório foi confirmado em 17 de Agosto de 1758. Em 14 de Setembro de 1758 foi emitida uma carta régia determinando que o Directório e a elevação a vilas dos aldeamentos indígenas fosse aplicado em todas as capitanias do Brasil. O processo teve início logo a seguir, mas foi ainda mais pertinente depois da expulsão dos jesuítas em 1759. 
26. CARTA de Francisco Xavier de Mendonça Furtado a Fernando da Costa de Ataíde Teive, datada de 16 de Março de 1769. Cf. Francisco A de Oliveira Martins (1938, p. 5-7)

27. CARTA de Francisco Xavier de Mendonça Furtado ao Desembargador João Inácio de Brito e Abreu, juiz de fora do Pará, 24 de Julho de 1758 BNP Colecção Pombalina 163 f. 47-50.

28. CARTA de Francisco Xavier de Mendonça Furtado ao ajudante José de Barros Machado, 16 de Outubro de 1758. BNP Colecção Pombalina 163 f. $167 \mathrm{v}$.
Mendonça Furtado da decisão régia de abandonar a praça de Mazagão na costa africana e de transferir os seus moradores para o Pará. Mazagão é, possivelmente, o nome mais evocativo entre as conquistas portuguesas do Norte de África. Refere-se à praça por mais tempo guardada, a melhor fortificada, e com uma história repleta de heróicos acontecimentos. Embora se tivesse, por mais de uma vez, cogitado abandoná-la em circunstâncias mais difíceis, esta permaneceu sob domínio português desde 1514 até 1769. Nesse ano, a hostilidade crescente das tribos no entorno da fortaleza e os ataques do sultão Sidi Mohamed ben Abdallah forçaram a evacuação.

É sem dúvida Mendonça Furtado quem decide o destino a dar aos povoadores da fortaleza do deserto, sugerindo ao rei a sua transferência para a Amazónia. Na carta que escreve ao governador do Pará, diz que "Com estas famílias ordena El Rei Nosso Senhor que se estabeleça uma nova povoação na costa septentrional das Amazonas, para se darem as mãos com o Macapá e com Vila Vistoza"26. A seguir, indica inclusive o local onde se deveria fazer a nova povoação para acolher os mazaganistas, no rio Mutuacá, mas adverte que o governador deveria enviar para a área pessoas capazes para decidir o local preciso da instalação da nova vila.

O governador efetivamente enviou o engenheiro Domingos Sambucetti para examinar o sítio mais cómodo para o estabelecimento da vila. Desta diligencia, o engenheiro deu conta ao governador escolhendo o "terreno místico ao lugar de Santa Ana no rio Mutuacá" do qual fez a planta, desenhando a nova vila sobre o povoado já existente (Figura 7).

Esta povoação de Santa Ana tivera origem num conturbado descimento de índios feito pelo capitão Francisco Portilho que, em 1753, "resgatara" 500 indígenas e os levara para Macapá para os vender como escravos. Proibido, por Mendonça Furtado, de concretizar negócio com os ditos índios, Portilho aceitou formar uma povoação, que se instalou inicialmente na itha de Santana, próximo à Macapá. $\bigcirc$ próprio Mendonça Furtado participou da criação do povoado, feita em 1754. Deste primeiro sítio, que se terá revelado pouco saudável, mudouse a povoação para as margens do rio Anapecuru, em 1756. A localização no rio Mutuacá era a terceira, da mesma povoação, feita já em 1769, no mesmo ano da decisão de transferência dos mazaganistas.

Desde 1758, entretanto, Mendonça Furtado já cogitara instalar um povoado naquele rio. Em carta sua, de julho daquele ano, dirigida a João lgnácio de Brito e Abreu, juiz de fora do Pará, comentara o provável estabelecimento de "um novo núcleo de fazenda e povoação de índios no rio Mutuacá, posto que tinha ótimos campos para currais" 27 . Alguns meses depois, em carta dirigida ao ajudante José de Barros Machado, comenta novamente o interesse que o principal Tomás manifestava em mudar-se para o Mutuacá, e o governador incentivava a mudança, pretendendo que se estabelecesse ali "uma povoação tão grande quanto a Vila de São José" 28

O interesse principal de Mendonça Furtado era, de facto, a Vila de São José de Macapá. Exortava a criação de outras povoações nas proximidades 


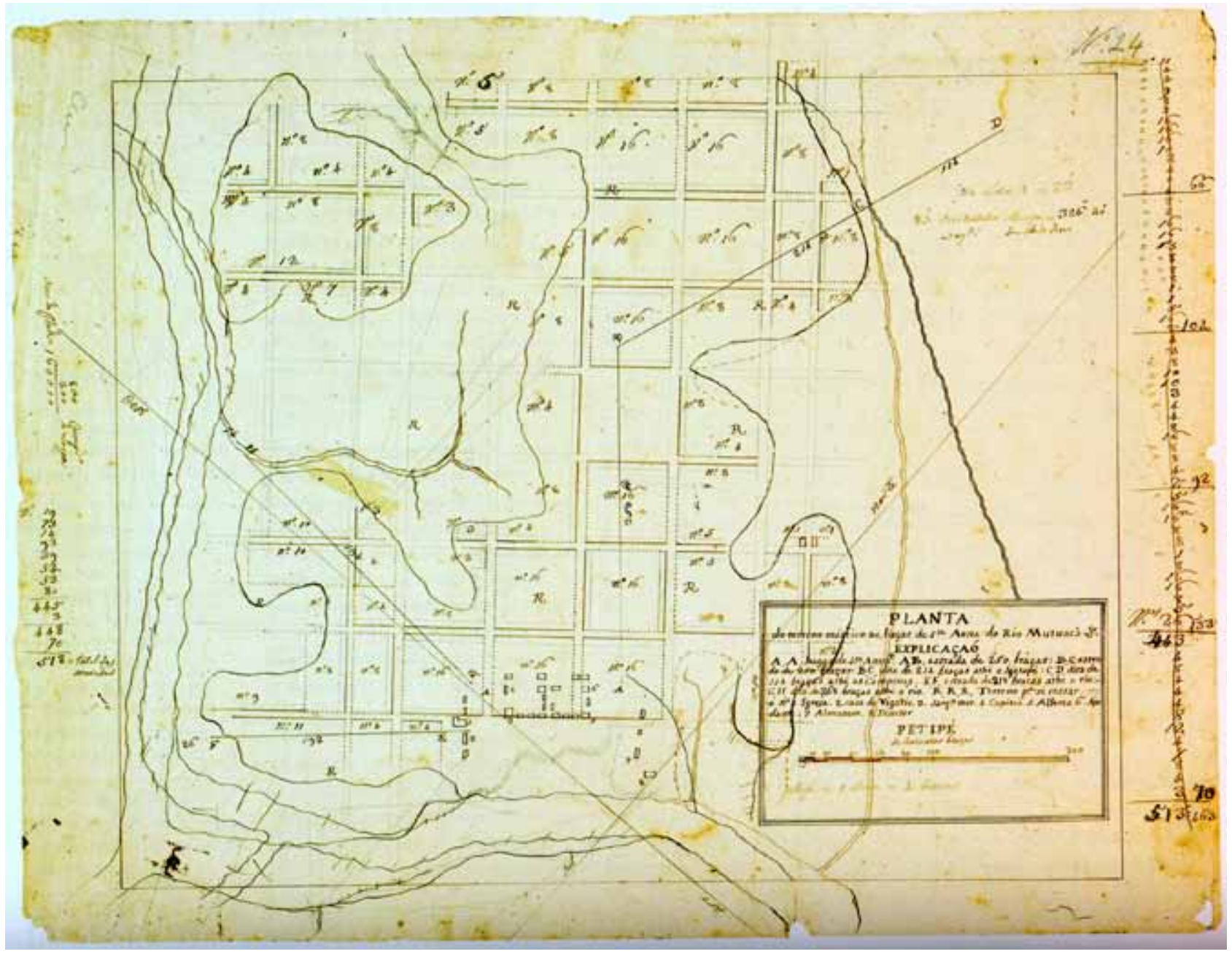

Figura 7 - Domingos Sambucetti, Planta do terreno místico ao lugar de S.ta Anna do Rio Mutuaca. Manuscrito. Casa da Ínsua cota n 24 (Garcia, 2002:202-203)

daquela vila, para que, em caso de perigo, os seus habitantes pudessem servir de reforço aos soldados da guarnição de Macapá.

Neste contexto se insere também a fundação da Vila Vistosa da Madre de Deus, feita em 1767. A vila foi fundada no rio Anapecuru, pelo desembargador Feliciano Ramos Nobre Gusmão, encarregado de tal pelo governador Fernando da Costa de Ataíde Teive. Segundo o relato da residência do desembargador, este "no breve espaço de seis meses a edificou com 112 casas armadas de madeira para os seus habitadores, igreja preparada para os mesmos ouvirem missa, com casa de residência para o parocho, tudo feito em bela regularidade"29. É a esta Vila Vistosa da Madre de Deus a que Mendonça Furtado se refere quando sugere que a nova Vila de Mazagão se fizesse "para darem as mãos com o Macapá e com Vila Vistoza".
29. RESIDÊNCIA do Desembargador Feliciano Ramos Nobre Gusmão. AHU Pará Caixa 818 - 28 de Junho de 1767. 
30. O título mais recente sobre o transporte das famílias de Mazagão para o Pará e a sua vivência em contínua espera é o livro de Laurent Vidal (2005).
Ao dar as mãos com Macapá, a Nova Vila de Mazagão alegoricamente fecha um ciclo na reforma urbana da Amazónia, levada a cabo por Mendonça Furtado e seus sucessores. A própria manutenção do topónimo da praça África faz referência direta à memória das conquistas e, concomitantemente, insiste na linha de homenagem ao poder régio seguida pelas demais fundações.

A primeira leva de mazaganistas saiu de Lisboa para o Pará em 15 de setembro de 1769. Dois meses depois, em 15 de novembro, morria Francisco Xavier de Mendonça Furtado. Apesar da resistência desde logo manifestada pelos mazaganistas, continuou-se o transporte das famílias para o Pará, feito em navios da Companhia de Comercio e sob rigoroso controle da Coroa, que procurava evitar a todo custo as deserções. $\bigcirc$ mesmo controle continuaria a ser exercido em Belém, onde as famílias esperavam para ser transferidas para a nova vila, à medida que as casas iam ficando prontas ${ }^{30}$.

O projeto da Nova Vila de Mazagão conta com um acervo ímpar de desenhos, o que permite acompanhar seu processo de concepção e construção. Há levantamentos prévios da área geográfica de instalação da vila. Há desenhos preparatórios em que se apontam os números dos habitantes e em que se fazem as contas da sua distribuição pelo espaço. Há ensaios de desvios da malha para, provavelmente, adaptar-se às áreas alagadiças ou inundáveis nas cheias do rio. Há desenhos das diferentes tipologias das casas a serem construídas: para casados e para solteiros. Há esquiços e há desenhos passados a limpo. Em todos, é evidente a determinação em fazer uma vila regular e formosa.

Embora se instale sobre uma povoação pré-existente, o projeto de Nova Mazagão define-se como uma fundação ex-nuovo. O Lugar de Santa Ana é praticamente desprezado por Sambucetti, que desenha a malha da nova vila ignorando a da antiga povoação de índios. Mesmo a igreja, que é o único edifício preservado, não se insere completamente na nova estrutura proposta, ficando marginal a ela.

Tal atitude pode estar associada a um problema de escala, considerando-se que a povoação existente tinha dimensões muito reduzidas para a quantidade de colonos novos que receberia. Sempre seria necessária uma ampliação do seu tecido urbano. O facto de este ter sido, no entanto, submerso no novo projeto, em vez de simplesmente ampliado, aproxima a hipótese escolhida de uma atitude intencional de separação entre os dois momentos.

A grandeza do investimento que se fazia não se coadunava com a escala humilde da povoação de índios. A relação de proporção entre a nova vila e $\mathrm{o}$ antigo lugar expressa-se em medidas radicais: as dimensões de apenas duas quadras de Nova Mazagão (60 × 60 braças cada; cerca de 132 × 132 m) são equivalentes às de todo o conjunto da antiga povoação. A construção do projeto explora uma certa dubiedade nos conceitos da vila que se fazia "novamente" fundando a Mazagão africana outra vez na Amazónia -, e a que se construía "de novo" - a "vila nova" e grande que abrigaria os colonos. A ação realizada sobre a velha povoação reforça ambas as acepções. A vila que então se fazia era tanto uma nova vila como uma vila reformada. Assim como também se 
pretendia fazer ver a situação da Mazagão deixada em África, reconstruída na Amazónia, sob nova forma e reformada.

É inevitável o paralelo com a situação descrita por Horta Correia para Vila Real de Santo António, assim como com o próprio conceito de RestauraçãoRessurreição, válido para o contexto do Algarve e da Amazónia no período pombalino ${ }^{31}$. No entanto, enquanto alegoricamente e em termos políticos a vila pretendia representar tal imagem, em termos práticos isso tinha custos bastante consideráveis. A contabilidade do investimento feito em Nova Mazagão foi várias vezes computada pelos governadores e, nas suas cartas à metrópole, a vila era referida como motivo de grandes preocupações. Os custos principais envolviam o dispêndio nas obras em si (com materiais e trabalhadores, recrutados entre a população indígena), mais o dinheiro necessário para sustentar os colonos enquanto estavam em Belém e, depois, outra quantia que thes era dada ao serem transferidos para iniciar o cultivo das terras. A referência a tais valores é uma constante na correspondência oficial. Mas os custos maiores eram, sem dúvida, os maus dividendos da inadaptação dos colonos à nova vila.

Desde o início, os mazaganistas levantaram dificuldades à sua instalação na Amazónia. Boa parte deles pretendeu escusar-se da vinda de Lisboa. Depois, chegados à capital do Pará, alegaram variadas razões para não passarem ao cabo do Norte. E, ao serem levados, sem alternativa, para a nova vila, lá, uma vez mais alegaram outros tantos motivos para saírem. Na razão direta do controle que a coroa pretendia exercer sobre a sua instalação, estes estabeleciam a resistência. Para além da insalubridade do clima, os mazaganistas alegavam sobretudo que os seus méritos guerreiros não se coadunavam com o papel de agricultores que se thes pretendia impor.

Já em 1773, João Pereira Caldas, o então governador do Grão-Pará, que enfrentava a contínua resistência dos mazaganistas de se mudarem para a nova vila, dizia que talvez fosse melhor deixá-los se instalar onde quisessem na região, o que acabou por ocorrer, cerca de 10 anos depois, em 1783, quando a rainha convenceu-se das sucessivas queixas sobre a alegada insalubridade do lugar e desistiu de obrigar os povoadores a mudarem-se para ali, exigindo, no entanto, que permanecessem na Amazónia.

Desenhar o Limite

Todos os governadores do Mato Grosso deixaram relatos, mais ou menos detalhados, das suas viagens inaugurais à capitania. A atribulada jornada de Rodrigo César de Menezes pelo caminho das monções foi narrada pelo ouvidor António Álvares Lanhas Peixoto. Já D. António Rolim de Moura não apenas fez, ele próprio, um circunstanciadíssimo relato da sua viagem, como mandou elaborar um mapa utilizando as medições que realizara ao longo do percurso desde Santos até Cuiabá. João Pedro da Câmara descreveu o seu trajeto pelo 
32. Ver INSTRUÇÕES que levou Luiz de Albuquerque de Mello Pereira e Cáceres quando foi nomeado governador e capitão-general da Capitania de Mato Grosso (13 de Agosto de 1771); cf. Gilberto Freyre (1968, p. 167). Kenneth Maxwell cita um trecho das Instruções remetidas ao Governador de Goiás, também em 1771 , que repetem textualmente essas afirmações sobre um "sistema fundamental" para a América Portuguesa ideado pelo Marquês de Pombal, cujas bases se fundavam na ajuda recíproca entre as capitanias especialmente nas questões relativas à defesa do território; cf. Kenneth Maxwell (1996, p. 128). caminho do Pará, através dos rios Amazonas, Madeira-Mamoré e Guaporé, enquanto Luís Pinto de Souza, que percorreu o mesmo caminho, enviou à Corte um relatório particularizado do rio da Madeira. Tal como os seus antecessores, Luís de Albuquerque de Melo Pereira e Cáceres também documentou o seu percurso de chegada ao Mato Grosso, tendo empreendido, no entanto, um caminho diferente de todos os outros, pois iria alcançar o Mato Grosso pelo centro do Brasil e, enquanto todos os seus antecessores tinham feito percursos maioritariamente fluviais, o seu seria praticamente todo por terra.

O caminho escolhido para a viagem do governador conformava-se como uma opção estratégica, como aliás já havia ocorrido no caso dos seus antecessores. No seu caso, a opção envolvia uma revisão e um aprofundamento das políticas até então seguidas no Mato Grosso, que Luís de Albuquerque iria progressivamente implementar ao longo dos 17 anos da sua administração, entre 1772 e 1789.

O novo governador tomou posse no dia 13 de dezembro de 1772 . Antes ainda de partir para o Mato Grosso, em agosto de 1771, recebeu em Lisboa, da mão de Martinho de Melo e Castro, as instruções gerais relativas ao governo da capitania. Tais instruções eram, na verdade, um conjunto de 15 cartas que tinham sido passadas aos seus antecessores, em diferentes ocasiões, entre 1757 e 1767. Segundo Martinho de Melo e Castro, aquelas cartas, elaboradas a partir das instruções do Marquês de Pombal, representavam "o sistema fundamental, que hoje forma o governo Politico, Militar e Civil de toda a America Portuguesa" 32 .

Tanto nas cartas emanadas diretamente de Lisboa, como nas instruções recebidas depois localmente, constata-se que a militarização e a defesa eram os grandes estruturadores do discurso. Recomendava-se, insistentemente, a criação de tropas especiais e a manutenção da vigilância e da operacionalidade da máquina de guerra. A essas considerações prioritárias seguiam-se as recomendações, que também thes estavam ligadas, para incentivar o crescimento económico da capitania de modo a garantir o seu sustento e, consequentemente, também a sua defesa.

É neste âmbito que surgem, como objetivos e como métodos, as políticas de incentivo ao aumento da população. Assim o maior número de habitantes deveria significar não só um maior desenvolvimento da capitania, como uma maior capacidade de defesa. A síntese desta política económico-militar preconizava-se na criação de novas povoações que deveriam conduzir ao aumento do número de habitantes da capitania, e responder pelo seu desenvolvimento económico e pela sua defesa. A liberdade dos índios servia como coadjuvante do mesmo processo, acrescentando povoadores e soldados.

No dia 18 de dezembro de 1772, cinco dias depois de ter tomado posse do governo da capitania, Luís de Albuquerque encaminhou à Corte uma petição dos moradores de Cuiabá que desejavam alcançar da "paternal clemência de Sua Mag.de" que mandasse fazer uma "Povoação e Fortaleza na margem Oriental do Rio Paraguai junto da barra do rio lpane ou no sitio 
denominado Fexo dos morros"33. As razões supostamente alegadas pelos cuiabanos para que se fizesse tal estabelecimento eram evitar as evasões de escravos, que fugiam pelo rio para Assunção, e também para a proteção dos moradores da capitania dos ataques dos índios Payaguás e Guaycurus. Afiançando tratar-se de um projeto de interesse, Luís de Albuquerque comunicou ao Conselho que enviaria o engenheiro Salvador Franco da Mota numa expedição ao rio Paraguai para examinar os locais indicados e para avaliar se eram próprios para construir a dita povoação e fortaleza.

Nesse pedido, feito em nome dos moradores, é evidente a tentativa de Luís de Albuquerque de retomar um projeto do seu antecessor Luís Pinto de Sousa Coutinho, anteriormente negociado com o governador da capitania de São Paulo, D. Luis António de Sousa Botelho Mourão, que previa que Cuiabá garantisse os mantimentos e que São Paulo fornecesse gente à nova colónia. Naquela ocasião, Sousa Coutinho também requisitou junto ao governador de São Paulo que este providenciasse a ida de um engenheiro à região, o que não chegou a ter lugar.

No entanto, passados cinco meses do envio do pedido dos cuiabanos, Luís de Albuquerque comunicou novamente ao Conselho o adiamento da expedição prevista ao rio Paraguai. Afirmava, nessa ocasião, que suspendia o projeto de exploração da margem do rio Paraguai, por essa ação no sul da capitania não ser compatível com as ordens régias que determinavam o seu deslocamento pessoal, bem como do engenheiro, para o norte da capitania, para fiscalizar a criação de fortificações e de novas povoações para instalar feitorias da Companhia de Comércio no rio Guaporé. Pelo mesmo motivo, dizia-se igualmente impossibilitado de dar prosseguimento a outro projeto que também tinha em mente, o de estabelecer um Registo no caminho de Goiás, para o qual já tinha inclusive escolhido o sítio ${ }^{34}$.

Mas enquanto o processo determinado pela Corte para o Guaporé iria ainda sofrer adaptações, Luís de Albuquerque procurou dar continuidade ao programa que expôs na carta de 25 de maio de 1773, deliberando ações de urbanização no sul, salvaguardando a defesa do rio Paraguai, e também no norte, no rio Guaporé, e no centro, no caminho de ligação com Goiás. É precisamente a esta carta que volta a referir-se quando, em janeiro de 1774, comunicou ao Conselho que se determinava a fazer, com os meios de que dispunha, tanto o Registo que tinha previsto no caminho de Goiás, como a regularização do Arraial de Arraes.

No primeiro caso, tratava-se simplesmente da implantação de um posto de registo e controle na estrada que conectava o Mato Grosso e Goiás. $\bigcirc$ governador, no entanto, advertia o encarregado para que cuidasse da eventual instalação de povoadores no local, prevenindo-o que tomasse as providências para esta se fizesse "formando rua direyta, ou outros espassos regulares q" paressam proprios" 35 . No segundo caso, tratava-se da ordenação do arraial de
33. CARTA de Luís de Albuquerque de Melo Pereira e Cáceres a Martinho de Melo e Castro. AHU Mato Grosso caixa 15 doc. 61 - 18 de Dezembro de 1772 .

34. Carta de Luís de Albuquerque de Melo Pereira e Cáceres a Martinho de Melo e Castro datada de 25 de Maio de 1773. AHU Mato Grosso caixa 15 doc. 91 - 1773 .

35. INSTRUÇÕES e Ordens que o Governador e Cap.m. General...AHU Mato Grosso caixa 16 doc 2.4 de Janeiro de 1774. [Instruções datadas de Novembro de 1773]. 
36. Ibidem.

37. Marcelino Roiz (1775), apud João Carlos Garcia (2002, p. 443).

38. CARTA de Luís de Albuquerque de Melo Pereira e Cáceres ao Marquês de Pombal.AHU Mato Grosso caixa 17 doc. 23 - 25 de Setembro de 1776 .

39. CARTA de Luís de Albuquerque de Melo Pereira e Cáceres a Martinho de Melo e Castro onde consta, ainda que "tomou posse para a Coroa de Portugal mandando levantar huma grande cruz de pau de Ley, limpar terreiro, fazer quartel e fogo nele, cassar nos matos vezinhos, pescar no Rio e passear de huma e outra parte no dito terreiro; dizendo com vozes altas, $1^{\text {a }}, 2^{\text {a }}$ e $3^{\text {a }}$ ves; Viva El Rey de Portugal; cujas palavras em igual voz todos os circunstantes repetimos outras tantas vezes: e para de tudo contar aos vindouros". AHU Mato Grosso caixa 18 doc. 36 - 21 de Setembro de 1778 .
Arraes, que se classificava como "informe e irregularissimo". O governador mandou o sargento-mor de Cuiabá, munido de instruções precisas que determinavam que deveria "proceder a hum novo alinhamento de ruas direitas com suas correspondentes travessas e mais partes de que costuma compor-se huma povoação sevilizada" ${ }^{36}$. Dando cumprimento às instruções recebidas, o sargento-mor enviou, em 20 de janeiro de 1775, o resultado da regulação em forma de desenho ${ }^{37}$ (Figura 8).

No final de 1775 e início de 1776, Luís de Albuquerque toma duas iniciativas fundamentais para a defesa da fronteira: o começo da construção do forte de Coimbra, no rio Paraguai; e da Fortaleza do Príncipe da Beira, no rio Guaporé. Em ambos os casos é visível o empenho do governador em estabelecer marcos inquestionáveis da posse portuguesa do território. A construção dos fortes seria ainda coadjuvada pela criação de novas povoações em suas proximidades.

A cerimónia do início da obras do forte do Príncipe da Beira realizouse no dia 20 de junho de 1776. Dois dias depois, o governador comunicava à Corte que o forte se encontrava já desenhado no chão e adiantava outros detalhes da sua construção. Informava ainda que pretendia, em sua viagem de volta para Vila Bela, fundar a povoação determinada pelas ordens régias, esperando que aquele "utilíssimo estabelecimento" pudesse prosperar tanto pelo mérito dos moradores, que o governador faria transportar para ali, assim como em função da feitoria de Comércio que esperava pudesse atrair ainda mais gente. Com efeito, em setembro do mesmo ano, Luís de Albuquerque remeteu ao Marquês de Pombal o auto de fundação da "nova Povoação denominada de Vizeu", que tinha sido criada, no dia 4 de setembro, "na margem occidental, ou esquerda do Rio Guaporé, quazi defronte do Rio Caraimbiara" 38 .

Dois aspectos são especialmente importantes relativamente a essa fundação. O primeiro deles é o facto de se esclarecer que o sítio da foz do rio Corumbiara localizava-se na margem esquerda, ou ocidental, do rio Guaporé. O segundo diz respeito ao que isto implica, pois Luís de Albuquerque alegava que voltava a instalar os índios da antiga aldeia de São José no primeiro lugar em que tinham estado aquando da sua primitiva fundação por D. António Rolim de Moura, também na foz do rio Corumbiara. A diferença é que desta vez estavam na margem ocidental e não na oriental.

Essa localização é relevante porque implicava colocar-se a povoação, deliberadamente, no outro lado rio, ou seja, no lado supostamente espanhol. Idêntica situação já se tinha passado na fundação do presídio de Coimbra, no rio Paraguai. $\bigcirc$ governador terá ordenado que se fizesse a fortificação no dito lugar de Fecho de morros onde, como já se disse, tinha-se pretendido instalar uma povoação desde o governo anterior. $\bigcirc$ oficial encarregado da missão terá "escolhido" a margem ocidental e não a oriental do rio. E o mesmo voltaria a acontecer exatamente dois anos depois da criação de Viseu quando, em 21 de setembro de 1778, o governador enviou à Corte o "Auto de posse, e Fundação do Lugar de Albuquerque, e seu destricto para a Coroa de Portugal" 39 . O lugar 


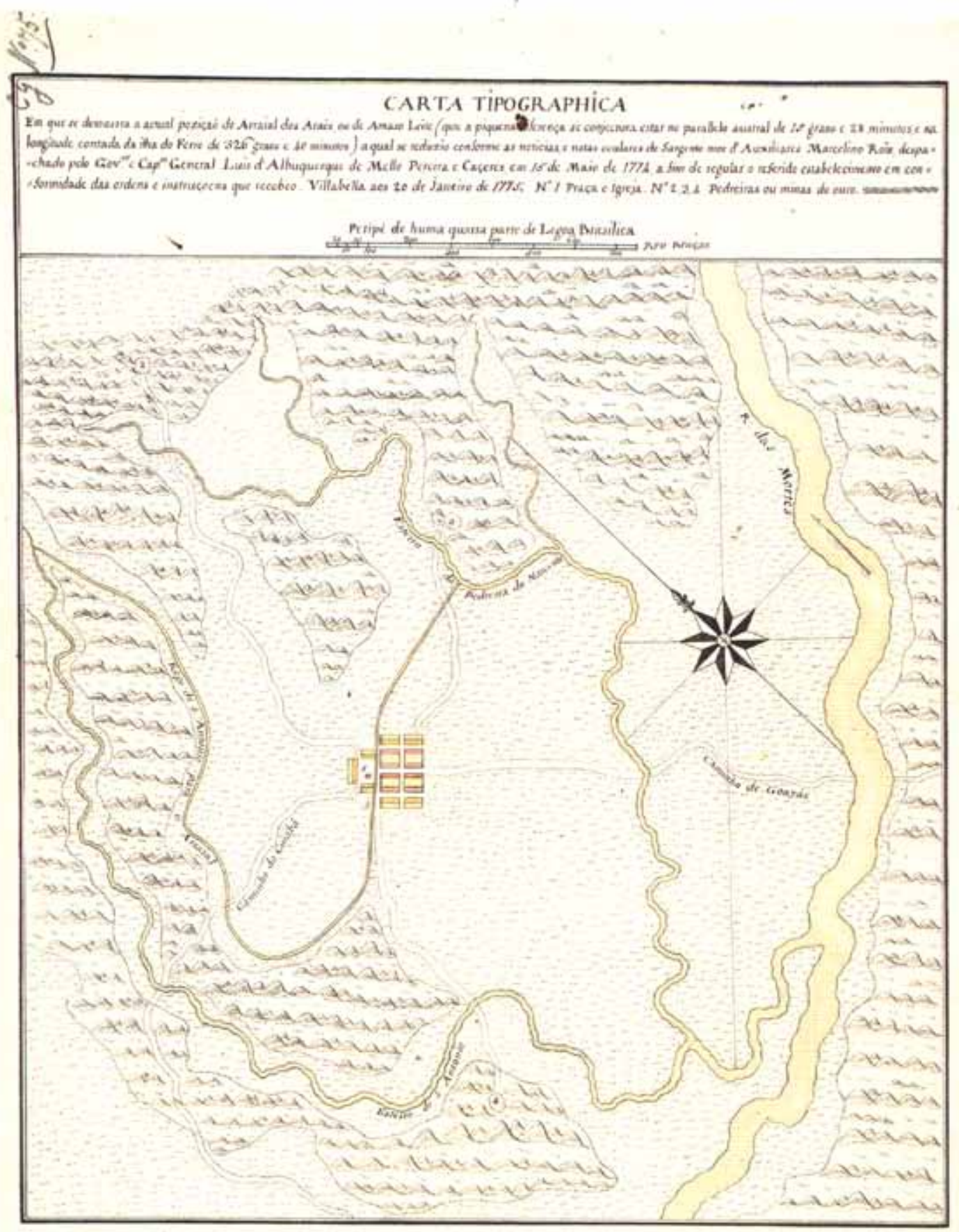

Figura 8 - Marcelino Roiz, Carta Tipographica em que se demonstra a actual posição do Arraial de Arrais ou de Amaro Leite (...) a qual se reduzio conforme as noticias e notas oculares do Sargento Mor d'Auxiliares Marcelino Roiz, despachado pelo Gov.or e Cap.m General Luís de Albuquerque de Mello Pereira e Cáceres em 15 de Maio de 1774 a fim de regular o referido estabelecimento em conformidade com as ordens e instruções que recebeo. Villa Bela 20 de Janeiro de 1775. Manuscrito. Arquivo Histórico Ultramarino, Lisboa, Cartografia Manuscrita Mato Grosso 855; Casa da Ínsua, cota CG 75 (Garcia, 2002:443). 
situava-se, uma vez mais, na margem ocidental do rio Paraguai algumas léguas acima do presídio de Coimbra (Figura 9).

Menos de um mês depois, outro termo de fundação subia ao conhecimento da rainha. Em 6 de outubro de 1778, foi criada a Vila Maria do Paraguai, desta vez em local inquestionavelmente português, no caminho já há muito estabelecido entre Cuiabá e Vila Bela. A nova povoação situava-se a cinco léguas do marco do Jauru, instalado pela partida demarcadora de 1754. Em ambas as vilas, uma grande praça retangular era o dado inicial da implantação urbana, o que remete para o sentido programático das famosas cartas de fundação de vilas que determinavam que se fizesse primeiro a praça e que, a partir dai, se deveriam fazer as ruas que mantivessem a sua "regularidade e formosura" (Figura 10).

Note-se a constância do processo e a contínua complementação do programa de ação que Luís de Albuquerque gizou para a capitania e que expôs à Corte na carta de 25 de maio de 1773. Importa, no entanto, referir que estas últimas iniciativas de Luís de Albuquerque de Melo Pereira e Cáceres fazem-se numa conjuntura muito específica. Em 1777, a morte de D. José I e a queda do Marquês de Pombal terão deixado, de certo modo, o governador mais à vontade quanto aos seus avanços no sul, para os quais nunca obtivera nem total anuência, nem a completa contestação do Marquês. Também as condições de guerra no

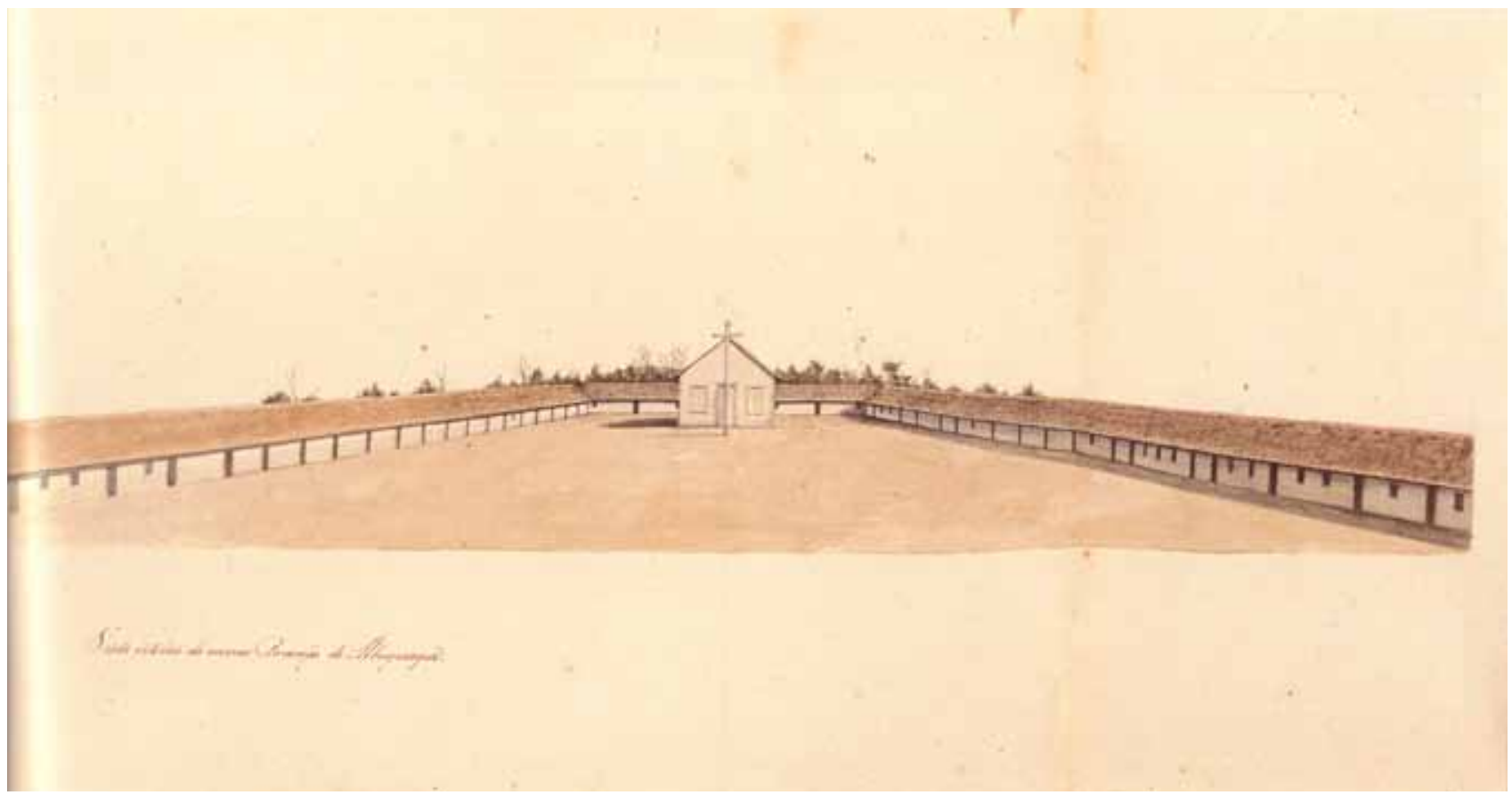

Figura 9 - José Joaquim Freire, (atr.), Vista interior da mesma Povoação de Albuquerque Colecção de desenhos da Viagem Filosófica de Alexandre Rodrigues Ferreira (folio nº 65). Manuscrito. Lisboa, Arquivo Histórico do Museu Zoológico Bocage. (Ferreira, 2002:1341 
Sul - com a tomada definitiva da Colónia do Sacramento e de Santa Catarina por Cevallos naquele mesmo ano e, especialmente, a queda do presídio do Iguatemi, que passavam a estar em mãos espanholas - foram decisivas para o reforço da intervenção no sul da capitania. Por outro lado, 1777 foi o ano da assinatura do Tratado de Santo Ildefonso, o que, sob vários aspectos, muito irá influir na ação do governador. Assim, é significativo que Luís de Albuquerque tenha dado à nova vila no Paraguai o nome da rainha, assumindo uma homenagem e, ao mesmo tempo, reivindicando o seu apoio.

Entre 1778 e 1780, Luís de Albuquerque vai empenhar-se na defesa política e ideológica das suas fundações. $\bigcirc$ objetivo, que virá defender na Idea Geral oferecida ao Real Conhecimento de Sua Magestade pelo actual Governador, e Capitão General da Capitania do Mato Grosso Luiz de Albuquerque de Mello Pereira e Caceres; de toda a Fronteira que forma a dita Capitania, a mais Ocidental do vasto continente do Brazil... 40 era garantir a navegação privativa dos rios da fronteira para Portugal, salvaguardando assim a possibilidade fazer a ronda do território pelo interior do continente, motivo pelo qual tinha fundado as povoações do outro lado dos rios Guaporé e Paraguai.

Assim, a "Ideia Geral" de Luís de Albuquerque apresenta-se em pelo menos dois níveis. Por um lado, era a explanação de uma ação concreta que já se vinha realizando no terreno e que continuava para além do enunciamento do
40. CARTA de Luís de Albuquerque de Melo Pereira e Cáceres a Martinho de Me lo e Castro datada de 20 de Agosto de 1780. AHU Mato Grosso caixa 20 doc $4-10$ de Agosto de 1780. O mesmo documento existe na Biblioteca Pública Municipal do Porto, cod. 464 (25-33v.).

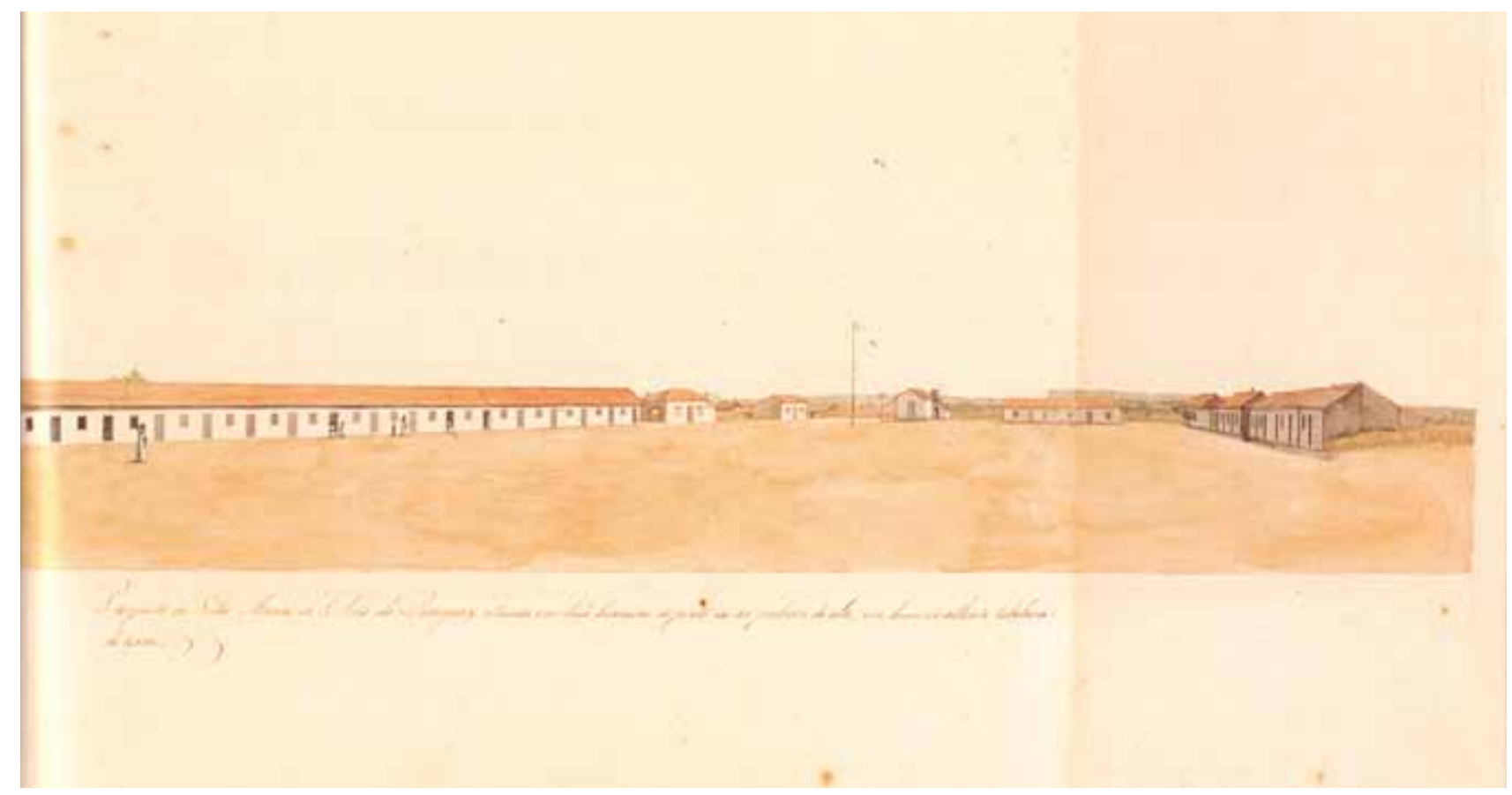

Figura 10 - José Joaquim Freire, Codina, Prospecto da Vila Maria e São Luís do Paraguai situada em uma barreira perto de 40 palmos de alto em um excelente taboleiro de terra. Colecção de desenhos da Viagem Filosófica de Alexandre Rodrigues Ferreira (folio n 58). Manuscrito. Lisboa, Arquivo Histórico do Museu Zoológico Bocage. (Ferreira, 2002: 118 ) 
41. CARTA de Luís de Albuquerque de Melo Pereira e Cáceres a Martinho de Melo e Castro. AHU Mato Grosso caixa 20 doc 49 - 24 de Julho de 1782

42. CARTA de Luís de Albuquerque de Melo Pereira e Cáceres a Martinho de Melo e Castro, datada de 27 de Novembro de 1783 . AHU Mato Grosso caixa 21 doc $42-24$ de Novembro de 1783 discurso. Por outro, era um "tratado" sobre o tratado de limites, que discutia as suas bases, contrapondo aos argumentos políiticos os argumentos geoestratégicos ditados pela experiência no terreno. Todo o discurso desenvolvido ao longo do texto de Luís de Albuquerque fundamenta-se nos dois grandes princípios da negociação: imposição versus persuasão. Numa frente discute-se, noutra age-se. A base da ação era a criação urbana, a base da discussão era a cartografia.

Os trabalhos de levantamento cartográfico e de efetiva marcação conceptual do território começaram a partir de 1782, quando chegaram os técnicos da comissão demarcadora. Entre as incumbências prioritariamente atribuídas aos engenheiros e matemáticos estava o pedido para que instruíssem algumas pessoas nos "primeiros elementos de geometria prática", tarefa essa que thes foi recomendada logo após a sua chegada à capitania ${ }^{41}$. A vigência dessa aula terá sido esporádica e informal, mas é seguro que funcionou como método de aprendizagem para alguns soldados.

Entre 1780 e o final da sua administração, em 1789, Luís de Albuquerque ainda iria estabelecer pelo menos mais duas povoações na capitania. Em 1781, criou a Vila de São Pedro del Rei. Tratava-se de facto de um arraial de mineração já existente nas Lavras de Peripoconé, descobertas em 1777, que o governador fez elevar a categoria de vila, dando-lhe um novo nome. Em 1783, foi criada, no rio Barbados, a nova Vila de Casalvasco. A intenção era sediar ali o encontro das comissões demarcadoras. A vila localizava-se ao sul de Vila Bela, numa região que o governador julgava imprescindível garantir para o território português, dado que ali se encontravam as nascentes dos rios Aguapeí e Alegre. Cada um desses rios pertencia, respectivamente, às bacias do Paraguai e do Amazonas, e a proximidade das suas nascentes representava, simbolicamente ao menos, a tão sonhada hipótese de circundar por via fluvial o território do Brasil. Do projeto da vila foi encarregado Joaquim José Ferreira, um dos engenheiros da comissão demarcadora (Figuras 11 e 12).

Casalvasco foi a última criação urbana de Luís de Albuquerque no Mato Grosso. Entre 1783 e 1789, o governador insistiu em sua políitica, dando prosseguimento a todas as ações iniciadas nos anos anteriores. Os grandes trabalhos realizados nesse período foram as expedições de levantamento cartográfico levadas a cabo pelos matemáticos e engenheiros. Depois do Guaporé e da região do istmo dos rios Alegre e Aguapeí, o rio Paraguai foi o grande objeto das explorações. A comitiva espanhola não chegou a vir a tempo de se realizarem as demarcações previstas, o que não impediu que continuassem, pela parte portuguesa, os trabalhos na fronteira. Ao contrário, foram ainda mais intensas as ações de exploração e levantamento, visando ao avanço dos conhecimentos sobre os oponentes. Luís de Albuquerque lembrava que não podia "dezaproveitar o prestimo dos mencionados officiaes pois que não vieram para o descanço"42. 
Na ocasião em que foi fundada a capitania do Mato Grosso, em 1748, a Coroa pretendeu expressamente que aquele território fosse o antemural do Brasil. Luís de Albuquerque fundou Casalvasco como um baluarte desse muro imaginário - o último baluarte de uma série que vinha construindo desde o início da sua administração, plantando povoações ao longo da fronteira.

Até aqui nada de novo. Terá sido este um sistema básico de sustentação de fronteiras e de territórios ao longo dos séculos. $\bigcirc$ que sobretudo diferencia a ação que se assiste no Mato Grosso (não apenas durante a administração de Luís de Albuquerque, mas que aí culminal é o literal delinear de um processo de construção territorial. Pois, para além de se constituírem como marcos operacionais do limite entre as potências litigantes, as povoações fundadas estão no centro de uma operação de desenho desse mesmo limite, que ultrapassa a sua situação pontual e abarca a sua relação territorial. Ou seja, o(s) mapa(s) - das áreas de

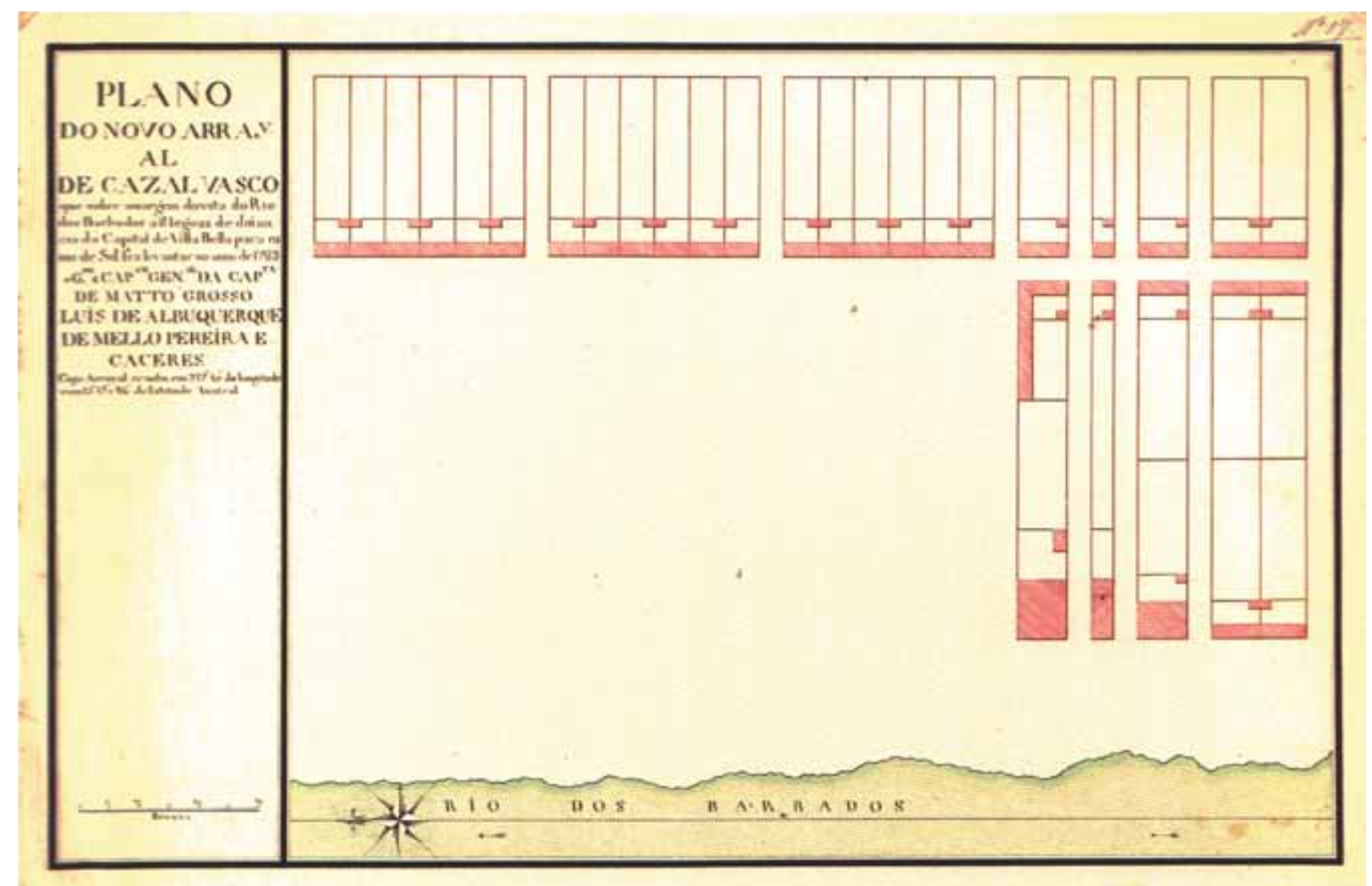

Figura 11 - Joaquim José Ferreira, Plano do Novo Arrayal de Cazal Vasco que sobre a margem direita do Rio dos Barbados a 8 legoas de distancia da Capital de Villa Bella para runo do sul fez levantar no ano de 1783 o Gor e Cap.am Gem.al da Cap,ta de Matto Grosso Luís de Albuquerque de Mello Pereira e Cáceres. Cujo Arayal se acha em $317^{\circ} 40^{\prime}$ de longitude e em $15^{\circ} 19^{\prime} 46^{\prime \prime}$ de latitude Austral. Manuscrito. Casa da Ínsua cota n 17 (Garcia, 2002:193) 


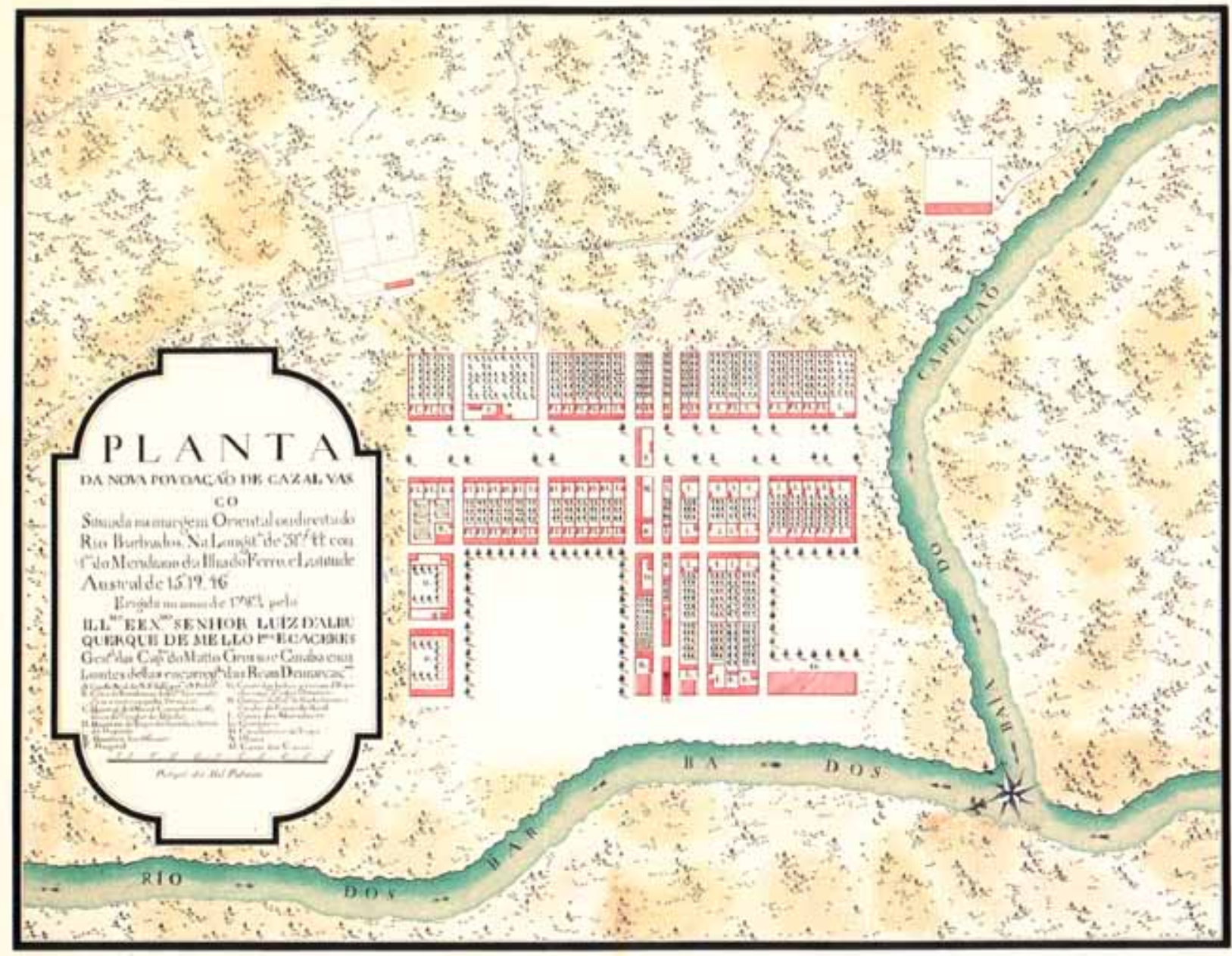

Figura 12 - Joaquim José Ferreira, Planta da Nova Povoação de Cazal Vasco situada na margem oriental ou direita do Rio dos Barbados. Na Longit.de de $317^{\circ} 44^{\prime}$ cont. dos da llha do Ferro, e Latitude Austral de 15¹9'46". Erigida no anno de 1782 pelo III.mo e Ex.mo Senhor Luiz d'Albuquerque de Mello P.ra e Caceres. Gen.al das Cap, tsa do Matto Grosso e Cuiaba e nos Limites delas Encarreg.do das Reais Demarcaç.oes. Manuscrito. Casa da Ínsua cota A 1 (Garcia, 2002: 306-307)

demarcação e do conjunto da capitania -, na medida em que se realizavam enquanto desenho, também se concretizavam enquanto território demarcado no próprio espaço. E as povoações eram tanto as balizas desse território como as suas frentes de construção.

Na verdade, as vilas e povoações que se fundaram quer na fronteira quer no interior dos matos e sertões foram as bases da construção do território como um todo. 


\section{REFERÊNCIAS}

\section{FONTES MANUSCRITAS}

Arquivo Histórico Ultramarino, Lisboa

CARTA de D. António Rolim de Moura ao Conselho Ultramarino.AHU Mato Grosso caixa 6 doc. 16 - 22 de Outubro de 1752.

CARTA de Luís de Albuquerque de Melo Pereira e Cáceres a Martinho de Melo e Castro.AHU Mato Grosso caixa 15 doc. 61 - 18 de Dezembro de 1772.

CARTA de Luís de Albuquerque de Melo Pereira e Cáceres a Martinho de Melo e Castro datada de 25 de Maio de 1773. AHU Mato Grosso caixa 15 doc. 91 - 1773.

CARTA de Luís de Albuquerque de Melo Pereira e Cáceres ao Marquês de Pombal.AHU Mato Grosso, caixa 17 doc. 23 - 25 de Setembro de 1776.

CARTA de Luís de Albuquerque de Melo Pereira e Cáceres a Martinho de Melo e Castro.AHU Mato Grosso caixa 18 doc. 36 - 21 de Setembro de 1778 .

CARTA de Luís de Albuquerque de Melo Pereira e Cáceres a Martinho de Melo e Castro datada de 20 de Agosto de 1780.AHU Mato Grosso caixa 20 doc 4 - 10 de Agosto de 1780

CARTA de Luís de Albuquerque de Melo Pereira e Cáceres a Martinho de Melo e Castro.AHU Mato Grosso caixa 20 doc $49-24$ de Julho de 1782

CARTA de Luís de Albuquerque de Melo Pereira e Cáceres a Martinho de Melo e Castro, datada de 27 de Novembro de 1783. AHU Mato Grosso caixa 21 doc 42 - 24 de Novembro de 1783.

CONSULTA do Conselho sobre os novos governos em Goiás e Mato Grosso. AHU Mato Grosso caixa 4 doc 2 - 29 de Janeiro de 1748.

CONSULTA régia sobre abertura do caminho do Guaporé com carta de D.António Rolim de Moura ao Conselho.AHU Mato Grosso caixa 6 doc 61 - 26 de Maio de 1753.

INSTRUCÕES e Ordens que o Governador e Cap.m. General [...] mandou passar ao Sargento-mor de Auxiliares Marcelino Roiz ao Arraial dos Araes sobre a margem ocidental do Rio das Mortes; com objecto de estabelecer os regulamentos de civilidade, Policia e boa ordem q'vão prescritos, e são dependentes dos exames e indagações q'ao mesmo vão ordenadas". Instruções datadas de Novembro de 1773.AHU Mato Grosso caixa 16 doc 2 - 4 de Janeiro de 1774.

INSTRUCÕ̃ES que levou Luiz de Albuquerque Mello Pereira e Cáceres quando foi nomeado governador e capitão-general da Capitania do Mato Grosso.AHU Mato Grosso Cod. 614, f. 1-8v.

MINUTA da carta régia datada de 5 de Agosto de 1746 determinando a criação de uma nova vila no Mato Grosso.AHU Mato Grosso caixa 3 doc 2.

RESIDÊNCIA do Desembargador Feliciano Ramos Nobre Gusmão. 28 de Junho de 1767.AHU Pará Caixa 818.

BIBLIOTECA NACIONAL DE PORTUGAL, LISBOA

INSTRUÇÕES régias recebidas por Mendonça Furtado. BNP Reservados Colecção Pombalina 626, f. 17 . 
CARTA de Francisco Xavier de Mendonça Furtado a Tome Joaquim da Costa Corte Real, 13 de Junho de 1757. BNP Colecção Pombalina 159, f. 51 v.

CARTA de Francisco Xavier de Mendonça Furtado ao Desembargador João Inácio de Brito e Abreu, juiz de fora do Pará, 24 de Julho de 1758. BNP Colecção Pombalina 163, f. 47-50.

CARTA de Francisco Xavier de Mendonça Furtado ao ajudante José de Barros Machado, 16 de Outubro de 1758. BNP Colecção Pombalina 163, f. 167v.

CARTA régia de 3 de Março de 1755. BNP Reservados cod. 11393 fl. 106.

CARTAS trocadas entre Francisco Xavier de Mendonça Furtado e D.António Rolim de Moura. BNP Colecção Pombalina, cod. 629.

CÓPIAS de cartas do Pará. Carta familiar e secretíssima em resposta das que havia recebido nas datas do mes de Novembro de 1752 sobre o governo interior dos Estados do Maranhão e Pará, datada de Lisboa 15 de Maio de 1753. BNP Reservados cod. 11393. fl. 89-105.

\section{BIBLIOTECA PÚBLICA MUNICIPAL DO PORTO, PORTO}

CARTA de Luís de Albuquerque de Melo Pereira e Cáceres a Martinho de Melo e Castro datada de 20 de Agosto de 1780. Biblioteca Pública Municipal do Porto, cod. 464, f. 25-33 v.

\section{FONTES ICONOGRÁFICAS}

FERREIRA, Joaquim José. Plano do Novo Arrayal de Cazal Vasco que sobre a margem direita do Rio dos Barbados a 8 legoas de distancia da Capital de Villa Bella para runo do sul fez levantar no ano de 1783 o Gor e Cap.am Gem.al da Cap.ta de Matto Grosso Luís de Albuquerque

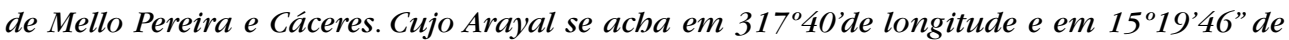
latitude Austral. Manuscrito. ca. 1783. Casa da Ínsua cota n. 17.

FERREIRA, Joaquim José. Planta da Nova Povoação de Cazal Vasco situada na margem orien-

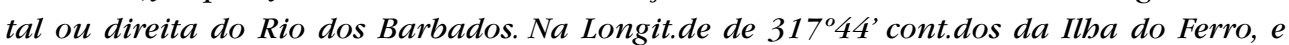
Latitude Austral de 15¹9'46”. Erigida no anno de 1782 pelo Ill.mo e Ex.mo Senbor Luiz d'Albuquerque de Mello Pra e Caceres. Gen.al das Cap,tsa do Matto Grosso e Cuiaba e nos Limites delas Encarreg.do das Reais Demarcaç.oes. Manuscrito. Casa da Ínsua cota A 1

FREIRE, José Joaquim [atribuído]. Vista interior da mesma Povoação de Albuquerque [s.d.] Colecção de desenhos da Viagem Filosófica de Alexandre Rodrigues Ferreira (folio n. 65). Manuscrito. Lisboa,Arquivo Histórico do Museu Zoológico Bocage.

; ou CODINA, Joaquim José. Prospecto da Vila Maria e São Luís do Paraguai situada em uma barreira perto de 40 palmos de alto em um excelente taboleiro de terra. [s.d.]. Colecção de desenhos da Viagem Filosófica de Alexandre Rodrigues Ferreira (folio n. 58). Manuscrito. Lisboa,Arquivo Histórico do Museu Zoológico Bocage.

GALLUZI, Henrique Antonio. Mapa Geral do Bispado do Pará repartido nas suas freguesias, que nelle fundou e erigio o Exmo. E Rev.mo Snr D. Fr. Miguel de Bulbões, III Bispo do Pará E construído e reduzido as regras da geografia com observações geomátricas e astronómicas pelo Ajudante Engenbeiro Henrique António Galluzi, 1759. Original.Acervo da BNRJ. 
GRONSFELD, Gaspar João de. Planta da Vila de S.José de Macapá tirada por ordem do Ilmo e Exmo Snr Manoel Bernardo de Mello e Castro Govor e Capp.am General do Estado do Para E em o Anno de 1761 pello Capitão Eng.ro Gaspar João de Gronsfeld.AHU Cartografia manuscrita Pará 789.

PLANO de Villa Bella da Santíssima Trindade Capital da Capitania de Mato Grosso levantado em 1789 Anno XXXII da sua fundação por ordem do Ill.mo e Ex.mo Senbor Luís de Albuquerque de Mello Pereira e Cáceres Governador e Capitão General a mesma Capitania no anno XVIII do seu felis governo. Manuscrito. Casa da Ínsua, Cota n. 1, Pasta n. 2.

ROIZ, Marcelino. Carta Tipographica em que se demonstra a actual posição do Arraial de Arrais ou de Amaro Leite [...] a qual se reduziu conforme as notiicias e notas oculares do Sargento Mor de Auxiliares Marcelino Roiz, despachado pelo Gov. e Cap. General Luís de Albuquerque de Mello Pereira e Cáceres em 15 de maio de 1774 a fim de regular o referido estabelecimento em conformidade com as ordens e instruções que recebeo. Villa Bela 20 de Janeiro de 1775. Manuscrito. Lisboa, Arquivo Histórico Ultramarino, Cartografia Manuscrita Mato Grosso 855; Casa da Ínsua, cota CG 75.

SAMBUCETTI, Domingos. Planta do terreno místico ao lugar de S.ta Anna do Rio Mutuaca. [s.d.] Manuscrito. Casa da Ínsua cota n. 24.

STURM, Filipe. Planta da Villa de Serpa erigida pello Illmo e Exmo Snr Joaquim de Mello e Povoas Gov.dor desta Cap.nia. Porj. e Deliniada pello Captam Ing. Philippe Sturm. Manuscrito. Lisboa, Biblioteca Nacional, Iconografia D $201 \mathrm{~A}$.

.Planta da Va de Silvez erigida pello Illmo Snr Joaquim de Mello e Povoas Gov.dor desta Cap.nia. Del. pello Captam Ing. Philippe Sturm. Manuscrito. Lisboa, Biblioteca Nacional, Iconografia D 199A.

LIVROS, TESES, DISSERTAÇÕES E ARTIGOS

ARAUJO, Renata Malcher de.As cidades da Amazónia no século XVIII: Belém, Macapá e Mazagão. 1992. Dissertação (Mestrado em História da Arte) - Faculdade de Ciências Sociais e Humanas, Universidade Nova de Lisboa, 1992.

. As cidades da Amazónia no século XVIII: Belém, Macapá e Mazagão. Porto: FAUP, 1998.

. A urbanização do Mato Grosso no século XVIII: discurso e método. Tese (Doutorado em História da Arte) - Faculdade de Ciências Sociais e Humanas, Universidade Nova de Lisboa, 2001a.

. O Mato Grosso: a fronteira a ocidente. In: COLÓQUIO INTERNACIONAL UNIVERSO URBANÍSTICO PORTUGUÊS 1415-1822, 1999, Coimbra. Actas... Lisboa: CNCDP, 2001b.

. Casal Vasco: a cidade, a fronteira e a floresta. In: COLÓQUIO LUSO-BRASILEIRO DE HISTÓRIA DA ARTE, 5. 2001, Faro. Actas... Faro: Universidade do Algarve-Faculdade de Ciências Humanas e Sociais, 2001c.

.A razão na selva: Pombal e a reforma urbana da Amazónia. Camões, Lisboa, n 15-16, p. 151 165, jan.-jul. 2003.

A Praça do Rei e a Praça do Marquês; espaço público, representação do poder e dinâmica social no projecto urbano de Macapá. In:VENTURA, Maria da Graça M.(Org). Os espaços de sociabilidade na Ibero-América (sécs. XVI-XIX). Lisboa: Colibri; Instituto de Cultura Ibero-Atlântica, 2004.

Desenhar cidades no papel e no terreno: cartografia e urbanismo na Amazónia e Mato Grosso no séc. XVIII. In: OLIVEIRA, Francisco Roque de; MENDOZA VARGAS, Héctor (Coord.). 
Mapas de metade do mundo. A cartografia e a construção territorial dos espaços americanos: século XVI a XIX [Mapas de la mitad del mundo. La cartografia y la construcción territorial de los espacios americanos: siglos XVI al XIX]. Lisboa: Centro de Estudos Geográficos da Universidade de Lisboa; Ciudad de México: Instituto de Geografía Universidade Nacional Autónoma de México, 2010a.p. 179-210 [Edição bilíngue].

. As vilas pombalinas da Amazônia: as cidades que tiveram ordem para serem mestiças. In: COLE, Douglas (Org.). Cortes, cidades, memórias: trânsitos e transformações na modernidade. Belo Horizonte: Centro de Estudos Mineiros, 2010b. p. 36-47. Disponível em:<http://www.fafich. ufmg.br/cem/livro.pdf>.

CORREIA, José Eduardo Horta. Pragmatismo e utopismo na criação urbanística de raiz portuguesa no século XVIII. Revista da Faculdade de Ciências Sociais e Humanas, Lisboa, n. 8, p. 103-112, 1995.

Vila Real de Santo António. Urbanismo e Poder na Política Pombalina. Porto: FAUP, 1997.

. A importância da arquitectura de programa na história do urbanismo português. In: COLÓQUIO LUSO-BRASILEIRO DE HISTÓRIA DA ARTE, 5. 2001, Faro. Actas.... Faro: Universidade do Algarve-Faculdade de Ciências Humanas e Sociais, 2001.

CORREIA FILHO, Virgílio. História de Mato Grosso. Rio de Janeiro: INL, 1969.

DELSON, Roberta Marx. New towns for Colonial Brazil espacial and social planning of the eigteenth century. Ann Arbor: University Microfilms International, 1979.

. Novas vilas para o Brasil-Colônia: planejamento espacial e social no século XVII. Brasília: Alva; Ciord, 1997.

FERREIRA, Alexandre Rodrigues. Viagem filosófica pelas capitanias do Grão-Pará, Rio Negro, Mato Grosso e Cuiabá 1783-1792. Rio de Janeiro: Conselho Federal de Cultura, 1971.

Viagem ao Brasil de Alexandre Rodrigues Ferreira: a expedição filosófica pelas capitanias do Grão-Pará, Rio Negro, Mato Grosso e Cuiabá. Documentos do Museu Bocage. Lisboa: Kapa, 2002. 2v.

GARCIA, João Carlos (Coord.). A mais dilatada vista do mundo. Inventário da Colecção Cartográfica da Casa da Ínsua. Lisboa: CNCDP, 2002.

MENDONÇA, Marcos Carneiro de. A Amazónia na Era Pombalina. Correspondência inédita do governador e capitão-general do Estado do Grão-Pará e Maranhão (1751-1759). São Paulo: Gráfica Carioca, $1963.3 \mathrm{v}$.

. O Caminho do Mato Grosso e as fortificações pombalinas da Amazónia. Revista do IHGB, Rio de Janeiro, v. 251, p. 3-32, abr.-jun. 1961.

MOREIRA, Rafael;ARAUJO, Renata.A engenharia militar do século XVIII e a ocupação da Amazónia. In: Amazónia Felsínea. António José Landi, itinerário artístico e científico de um arquitecto bolonhês na Amazónia do século XVIII. Lisboa: CNCDP, 1999. p. 173-295.

VIDAL, Laurent. La ville qui traversa l'Atalntique du Maroc à l'Amazonie (1769-1783). Paris: Aubier, 2005.

Artigo apresentado em 1/201 1. Aprovado em 12/2011. 